\title{
Terrorizing Zoroaster's Prophethood and the Opinion of Malay Gawra of Koya on Zoroastrianism
}

\section{Ala Dara Abdul Majid ${ }^{l}$}

Received: February 20, 2016

Reviewed: May 13, 2016

Accepted: May 20, 2016

\begin{abstract}
This research focuses on the prophecy or prophethood of the old Kurdish prophet Zoroaster and his book The Avesta. More than a century ago, the western printed sources and publications presented Zoroaster's doctrines and beliefs distortedly exploiting them to achieve their own aims; hence, this research throws light on this aspect .Another aspect of the research is the view of Malay Gawra of Koya, who was a distinguished ahead of their time. He believed in the existence of Zoroaster and his being a Kurd supported by the great explainers before him.
\end{abstract}

Keywords: Zoroaster, Malay Gawra, Kurdish poem, Koya.

$$
\begin{aligned}
& \text { كورته }
\end{aligned}
$$

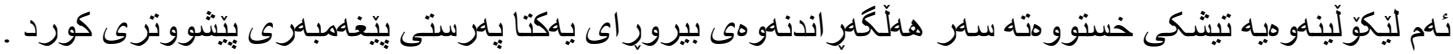

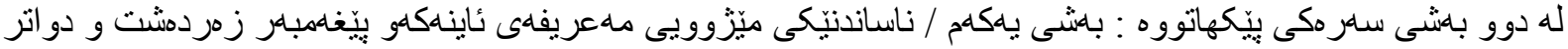

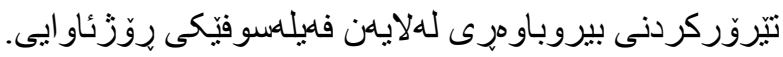

$$
\begin{aligned}
& \text { كليله وشهكان: زمردشت، مهلاى كاهور ره، شيعرى كوردى، كوّيه. }
\end{aligned}
$$

Recommended citation:

Abdul Majid, A. D. (2016). Terrorizing Zoroaster's prophethood and the opinion of Malay Gawra of Koya on

Zoroastrianism.

International

Journal of Kurdish

Studies

$2(3)$

22.

1 Assistant lecturer, Department of Kurdish language, Faculty of education, Koya University Daniel Mitterrand Boulevard, Koya KOY45, Kurdistan Region - F.R. Iraq. E-mail;

ala.dara@koyauniversity.org 


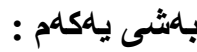

ماعريفهى ثاينى زمردمثتييككان:

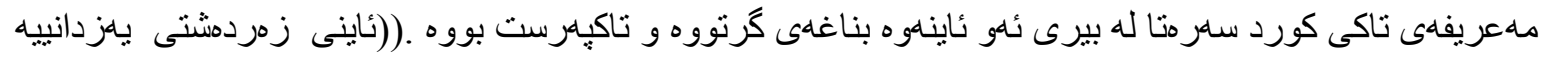

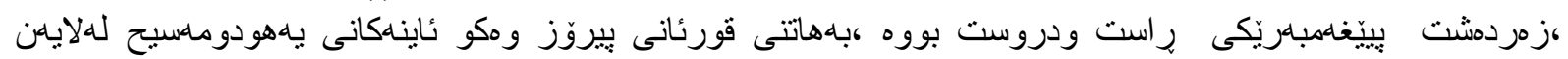

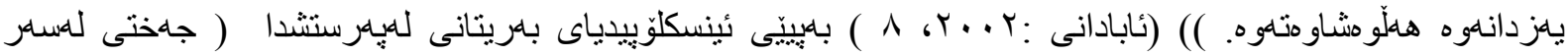

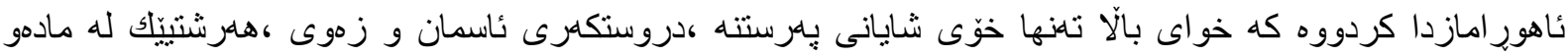

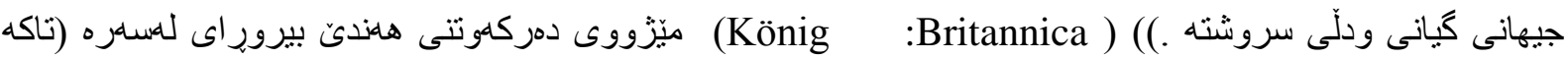

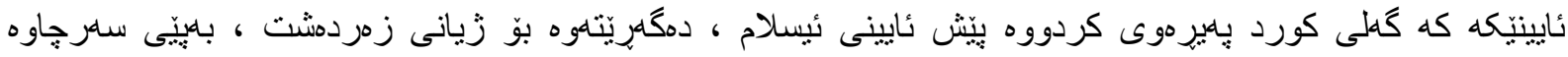

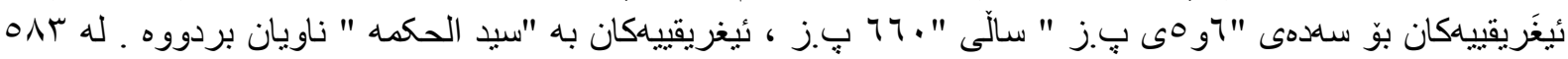

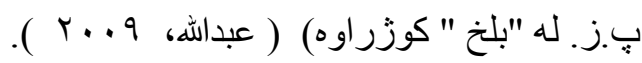

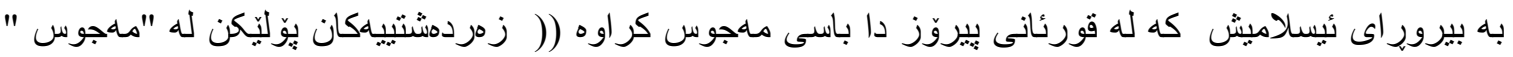

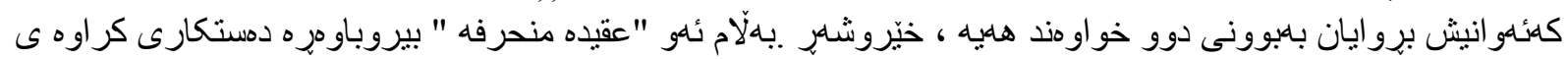

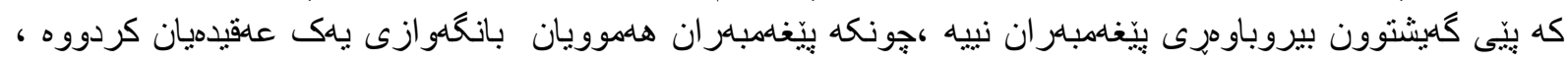

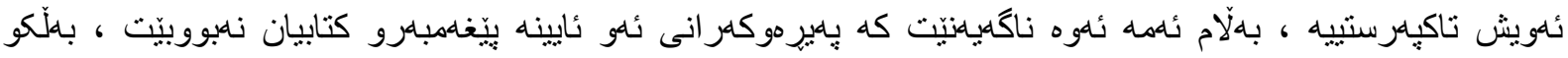

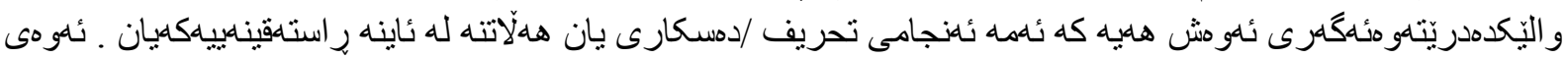

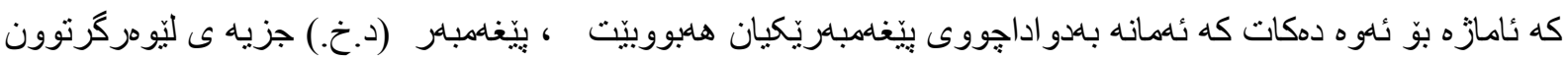

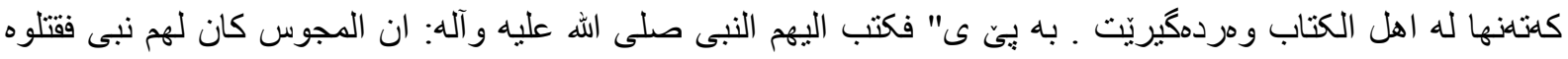

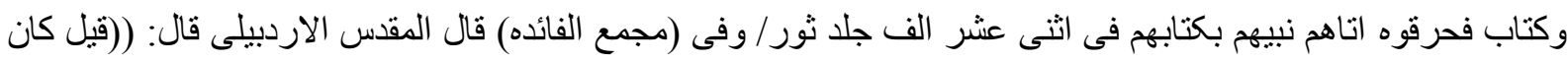

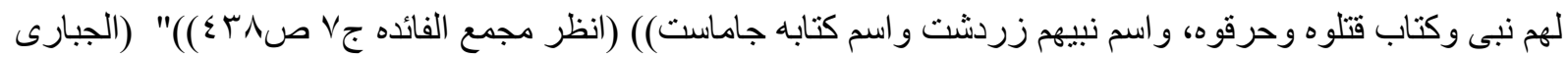

. ( r... व ،

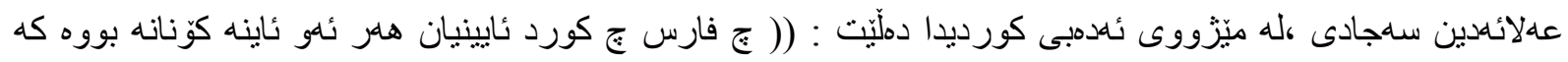

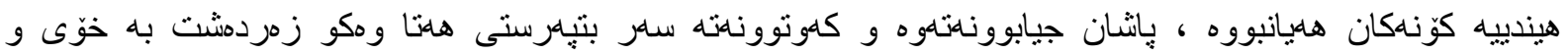

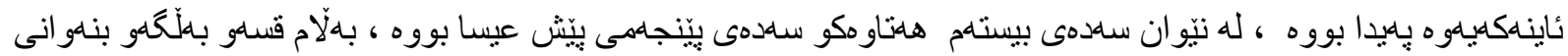

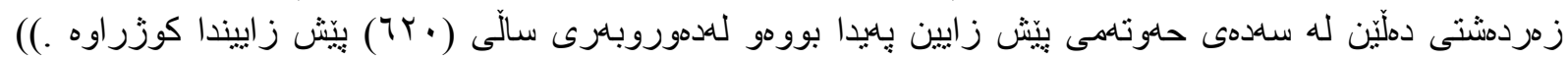

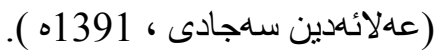

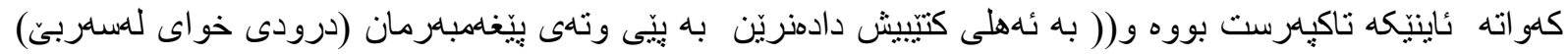

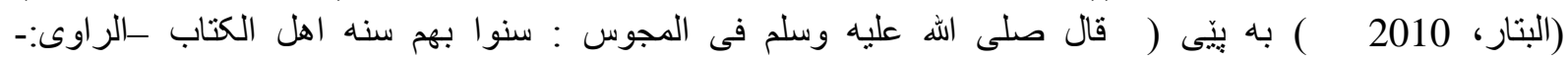

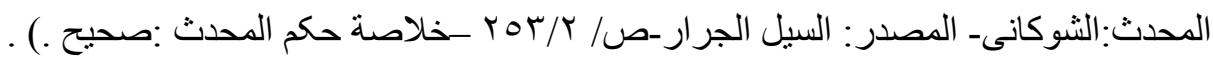

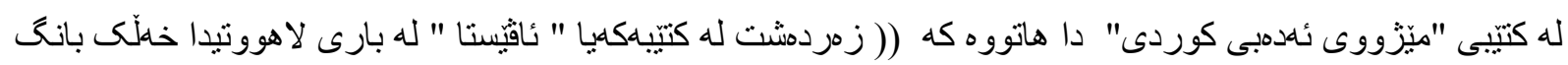

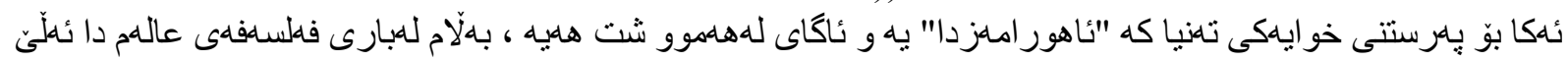

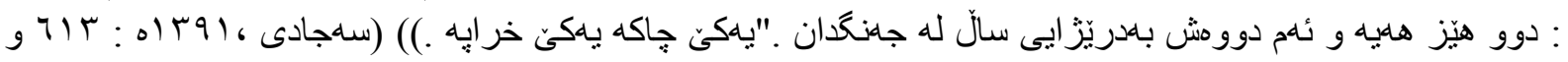

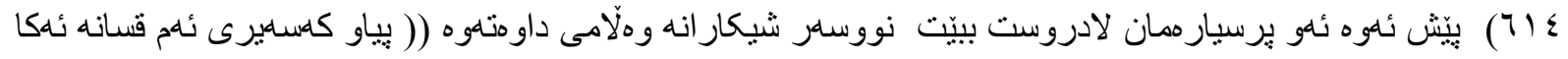

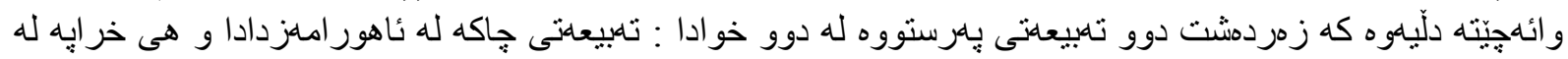

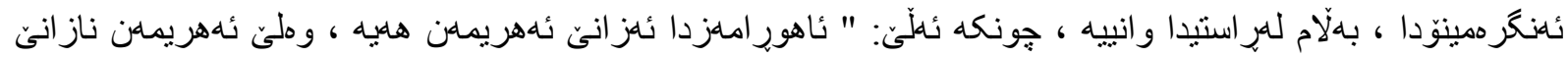

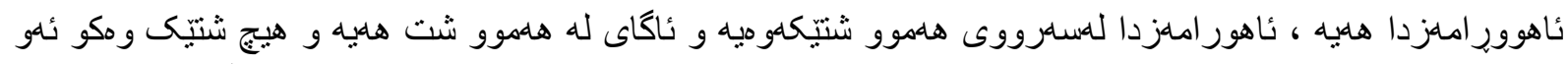

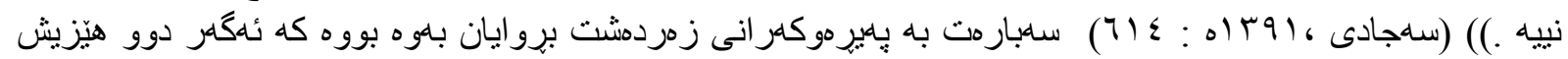

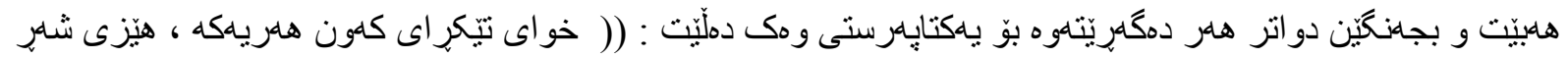

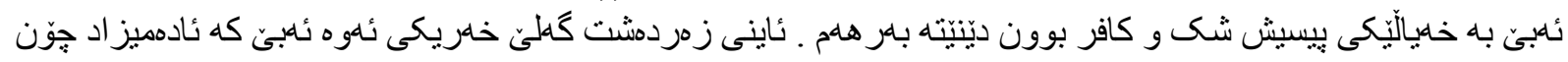

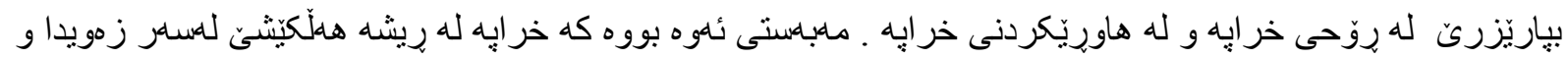

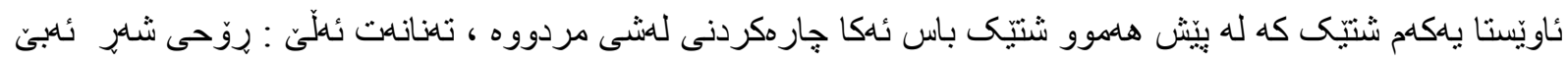




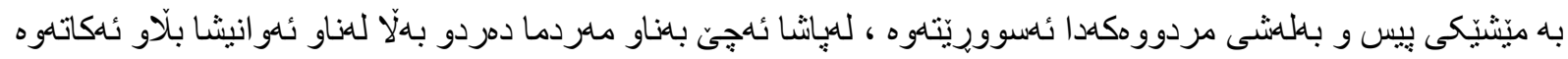

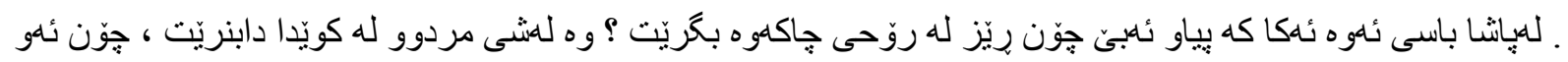

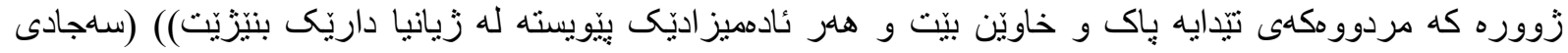

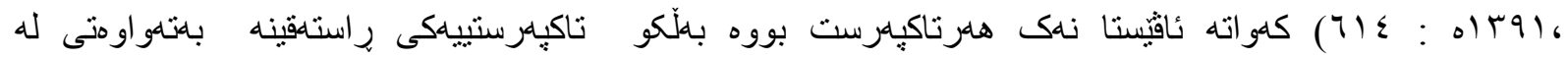

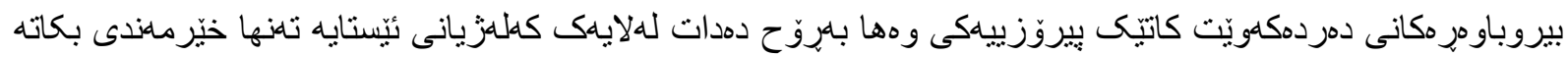

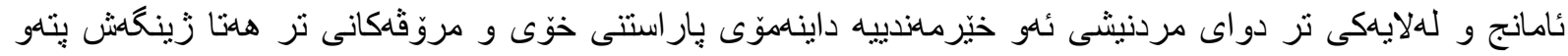

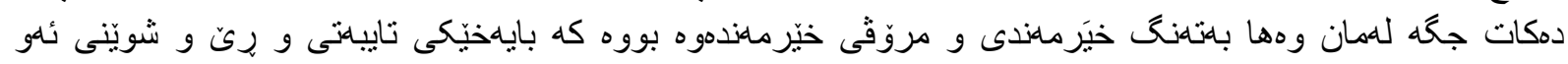

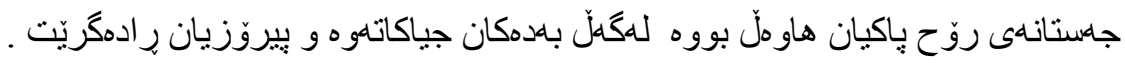

$$
\text { ئافرهت لاى زمردمثتبيهكان : }
$$

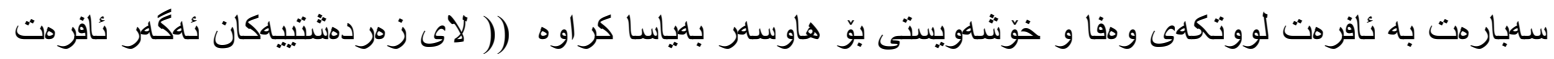

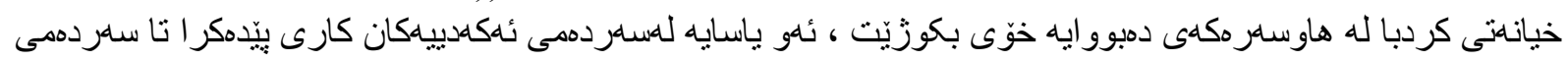

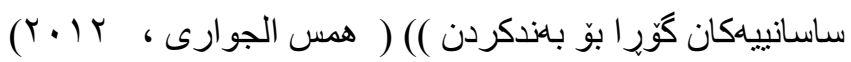

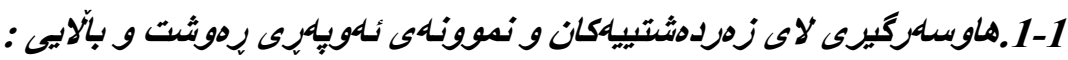

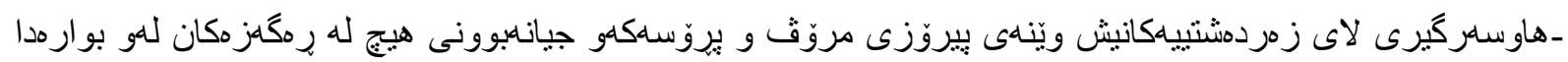

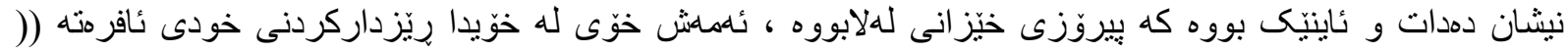

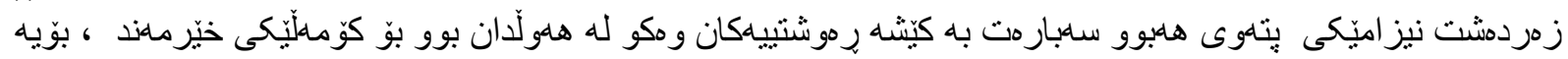

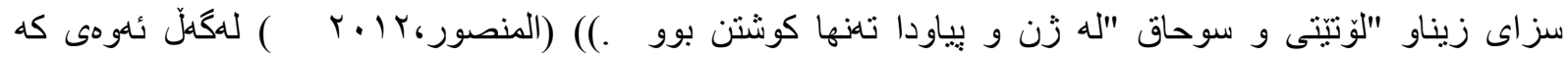

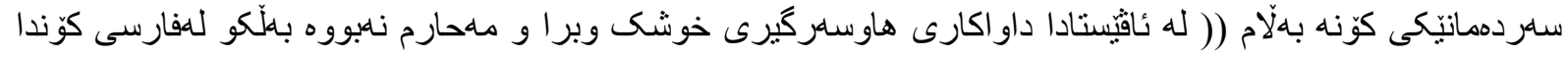

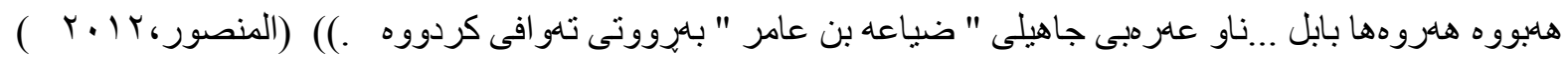

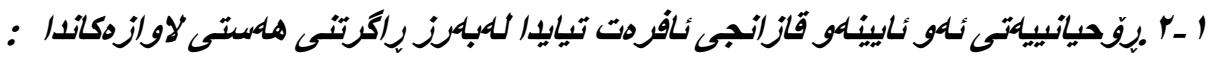

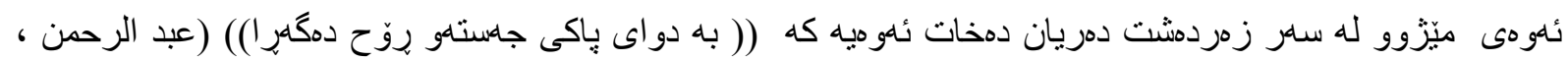

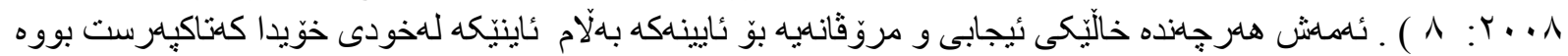

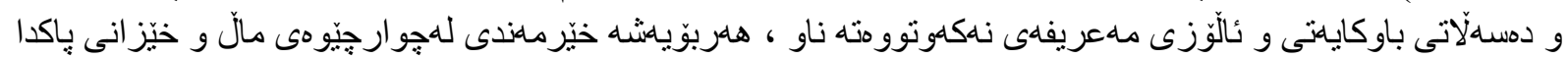

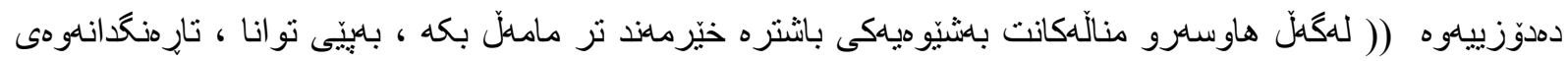

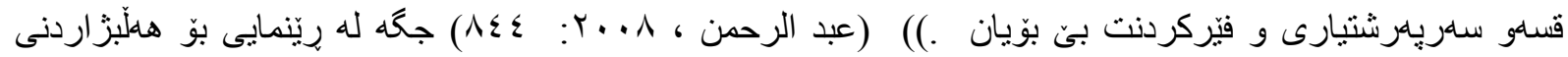

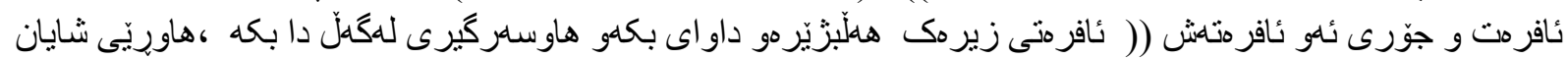

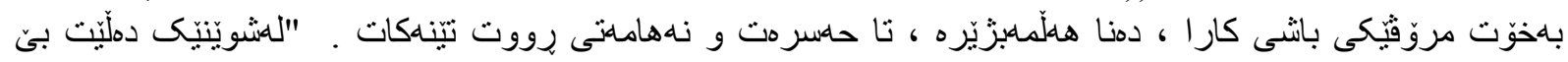

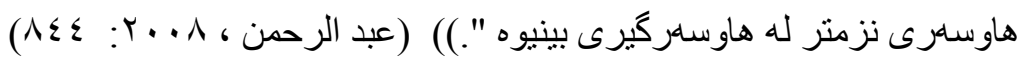

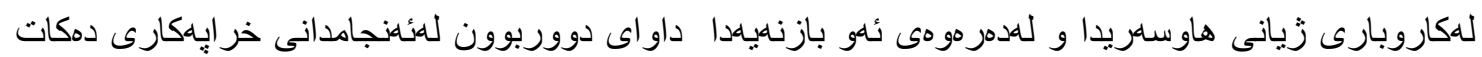

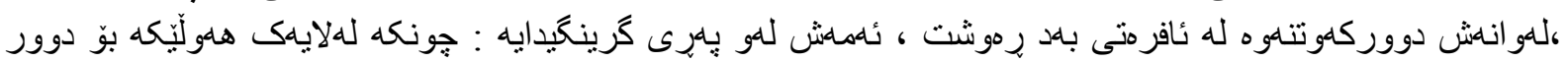

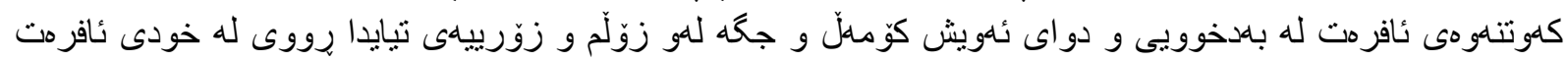

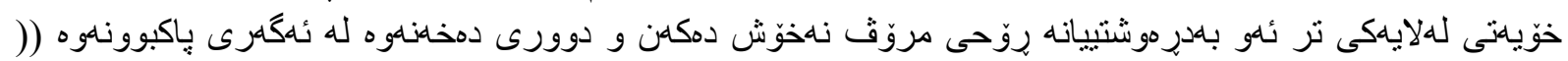

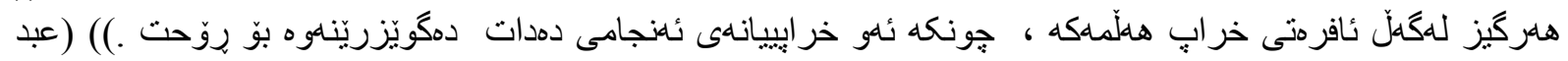

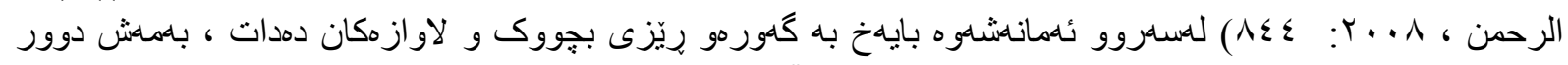

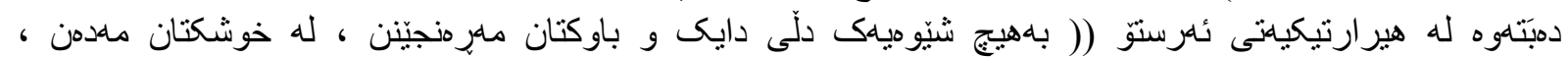

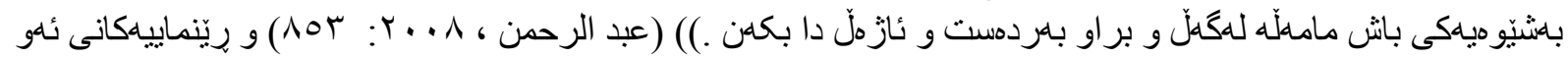

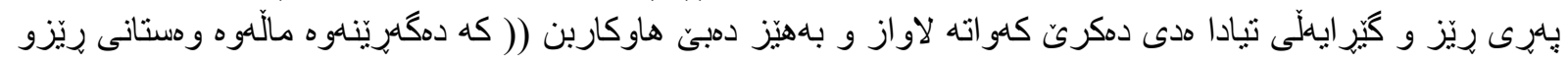




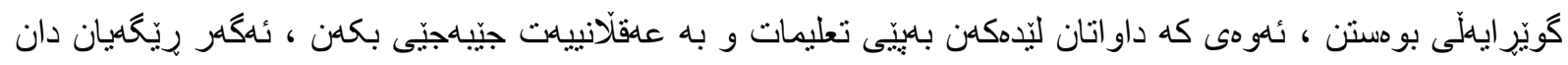

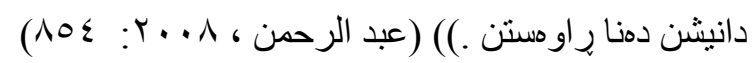

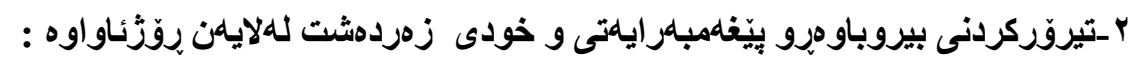

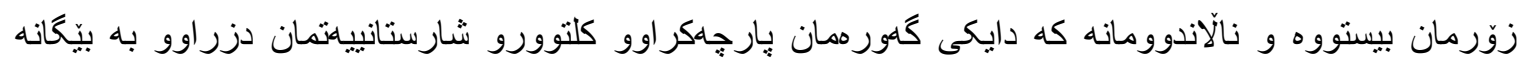

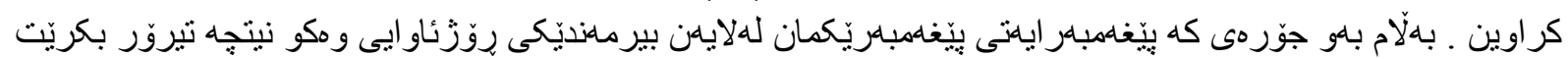

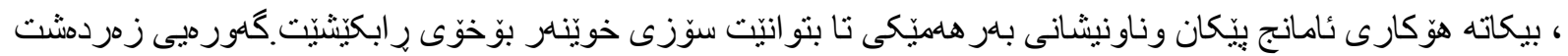

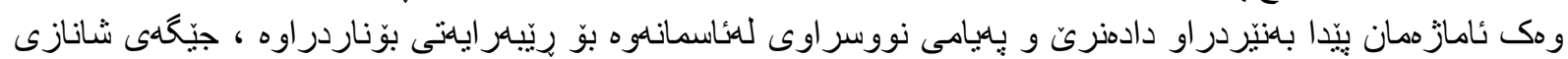

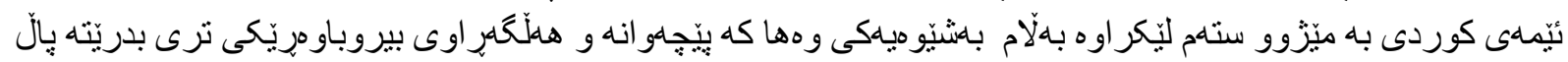

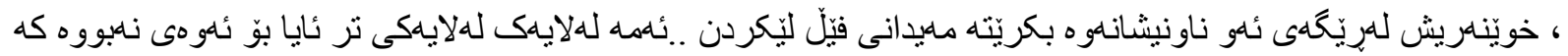

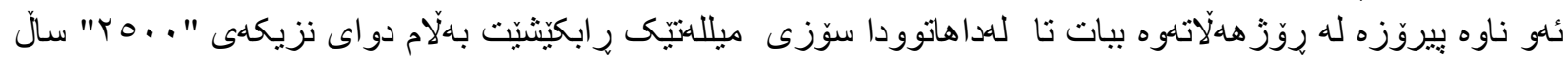

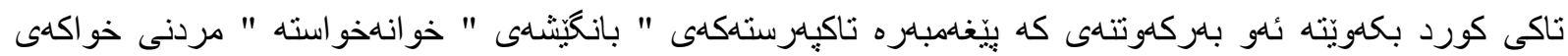

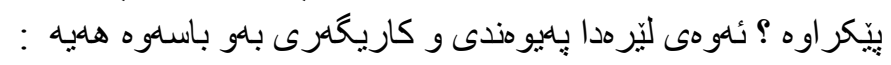

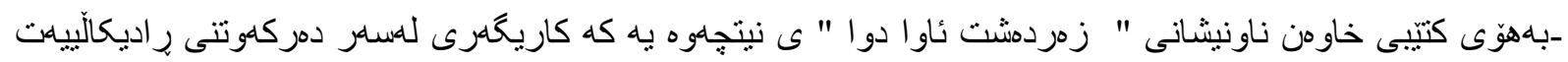

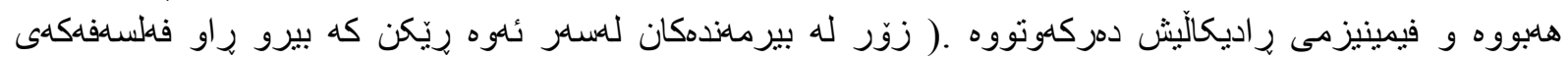

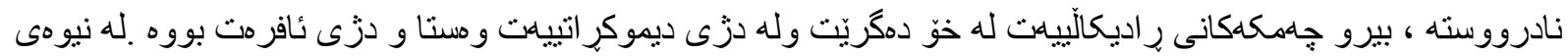

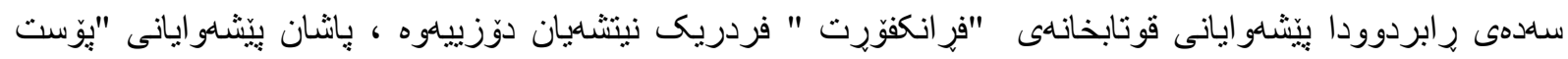

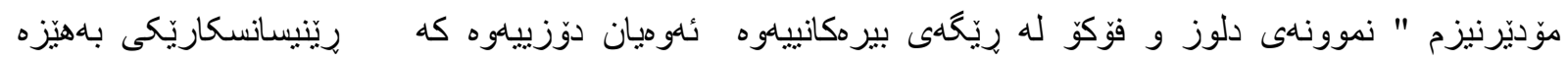

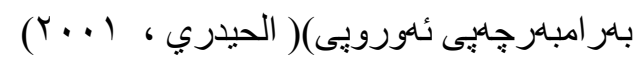

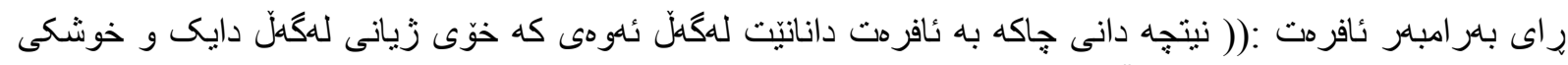

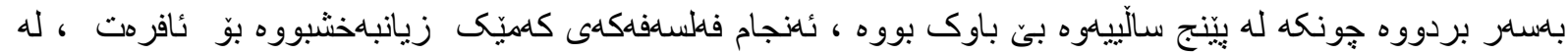

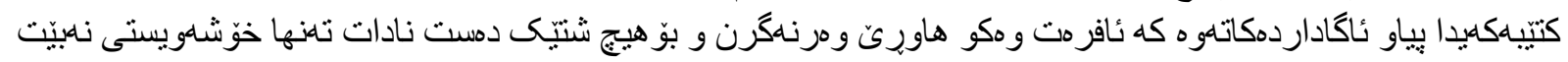

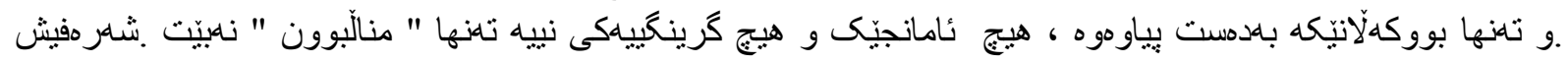

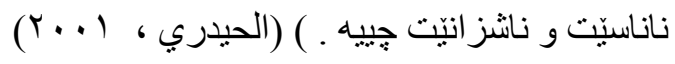

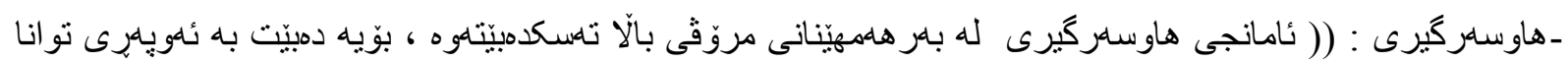

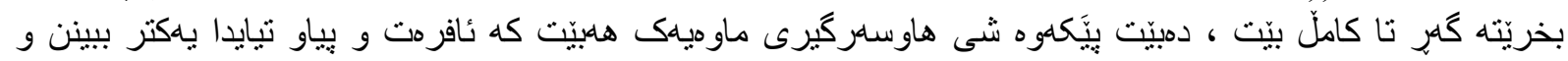

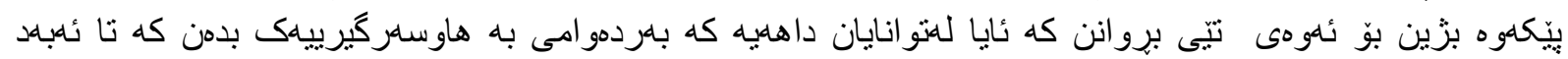

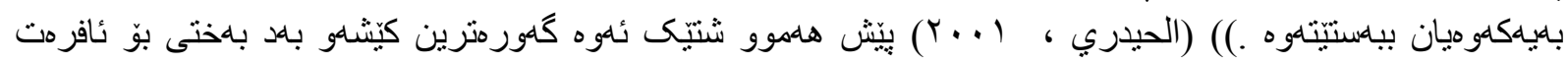

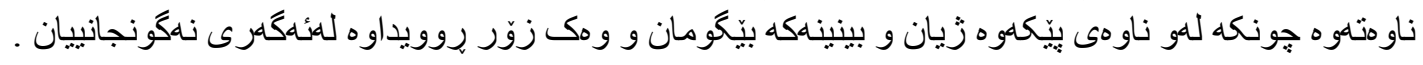

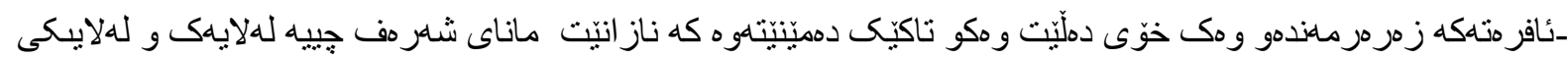

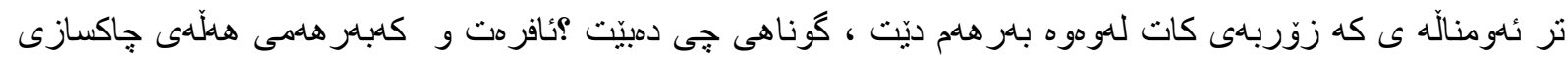

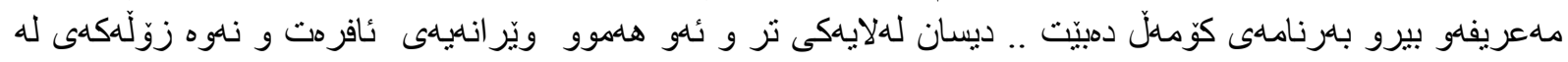

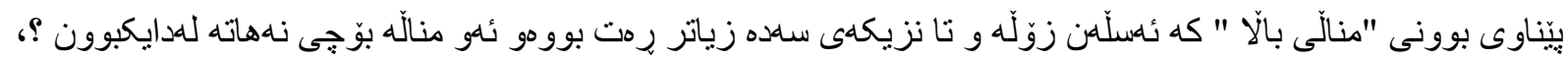

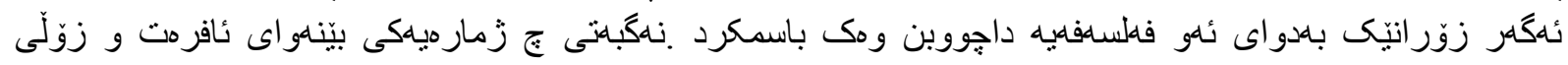

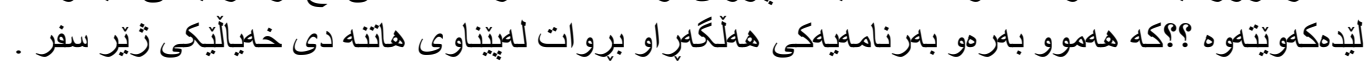

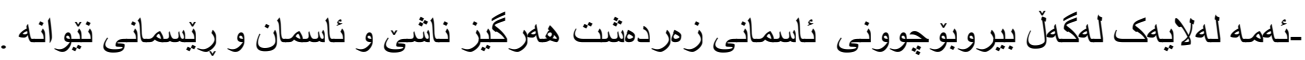

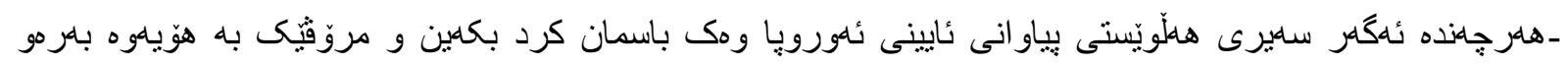

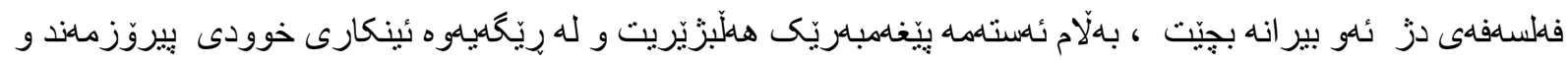




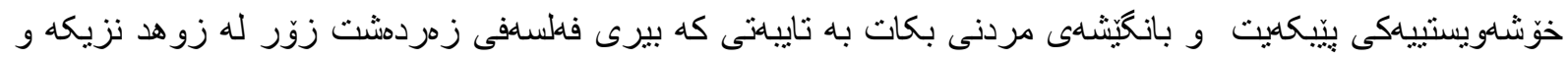

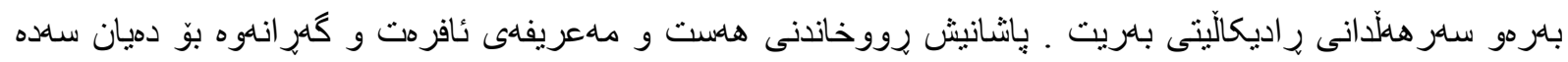

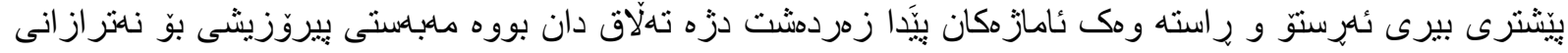

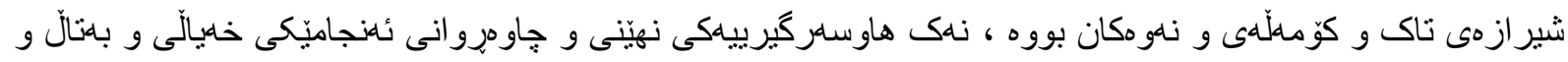

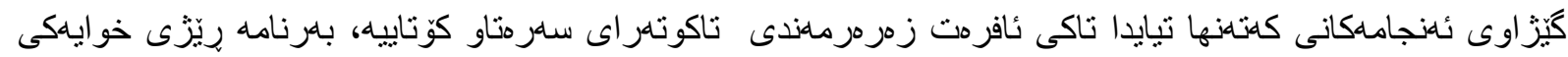

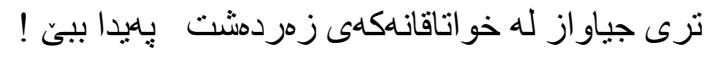

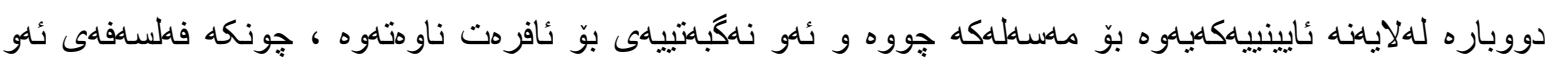

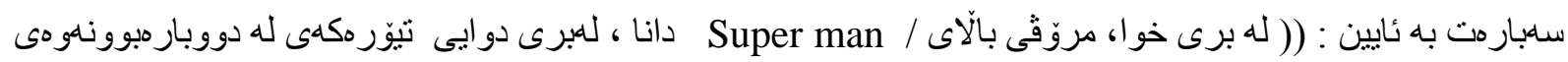

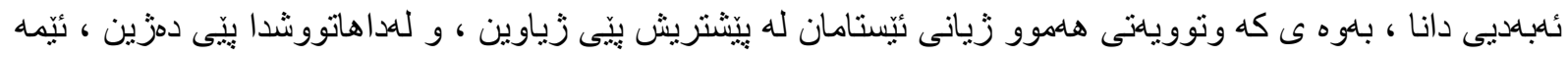

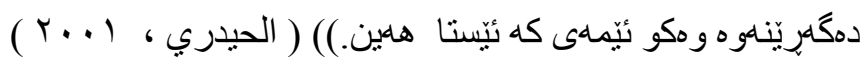

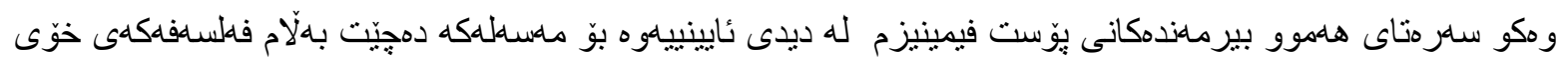

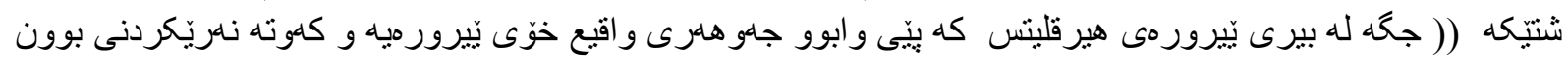

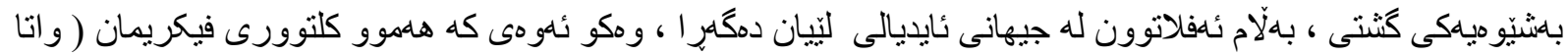

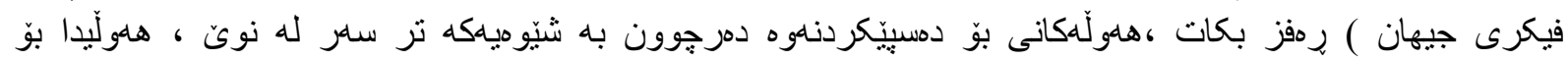

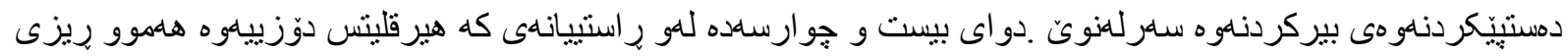

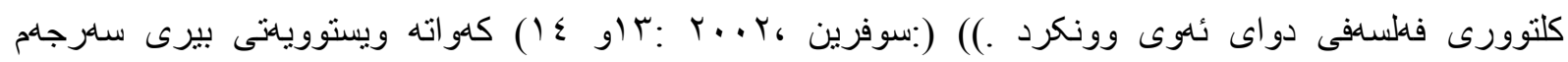

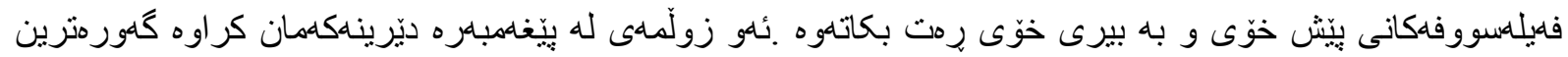

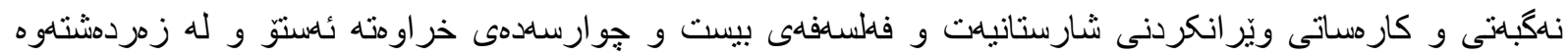

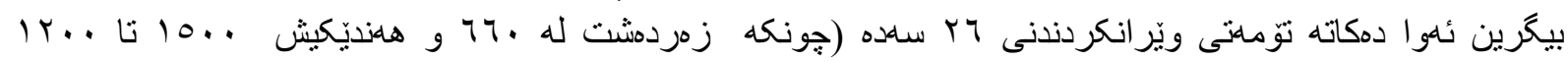

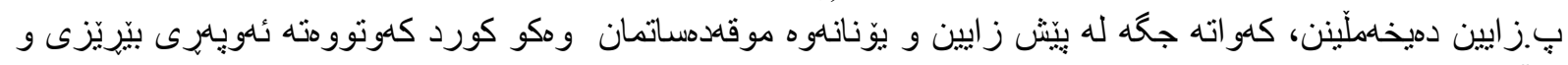

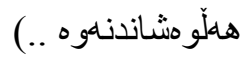

ب-لادانى نهمرى روّح و ناساندنى ومكو شنيّكى كاتى و للهناوجوونى :

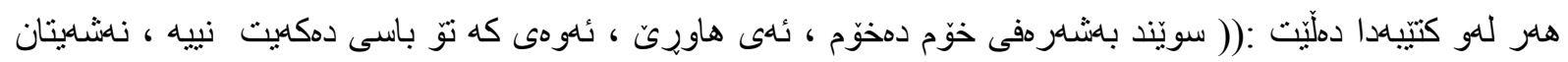

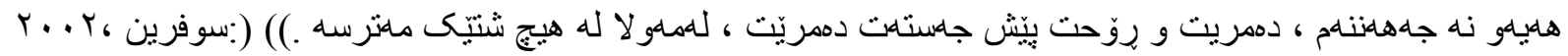

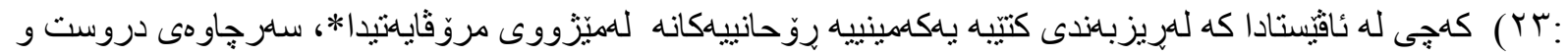

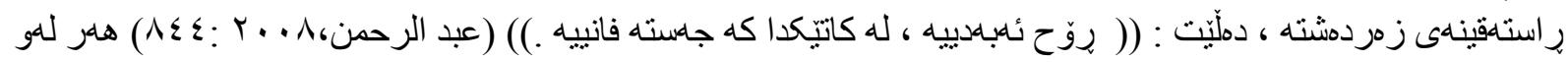

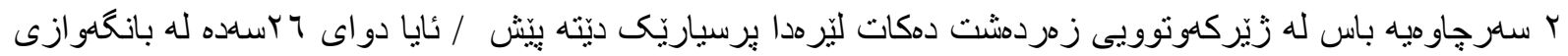

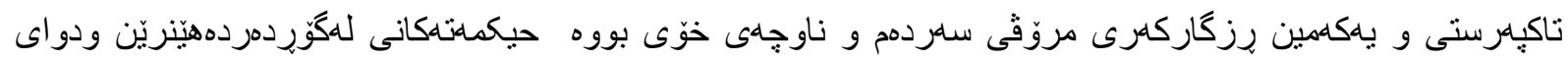

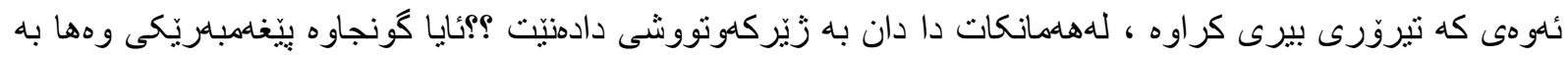

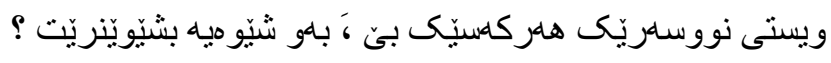

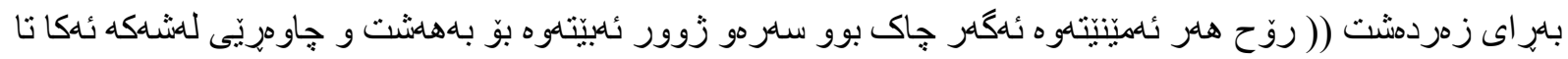

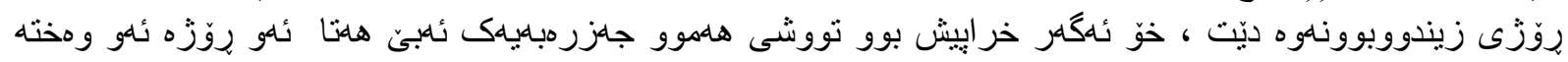

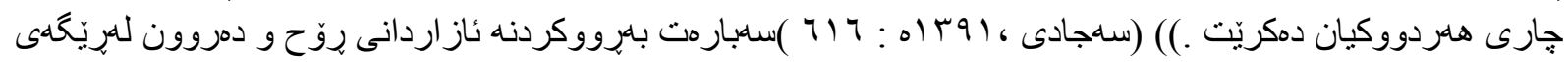

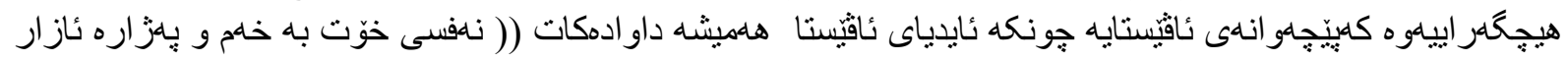

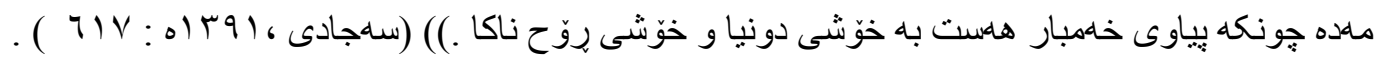

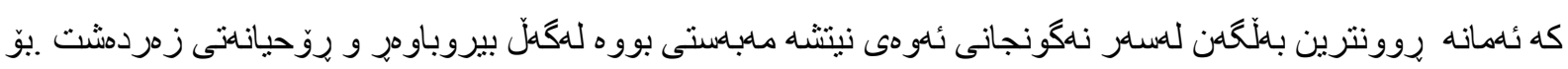

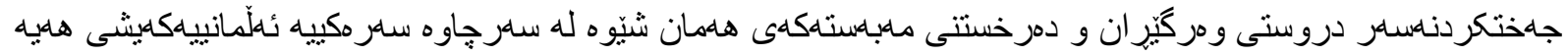

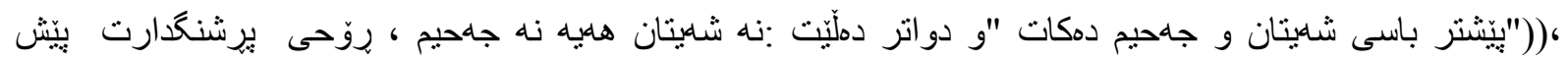

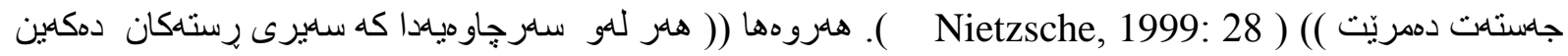

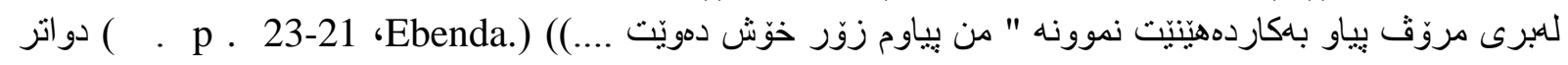




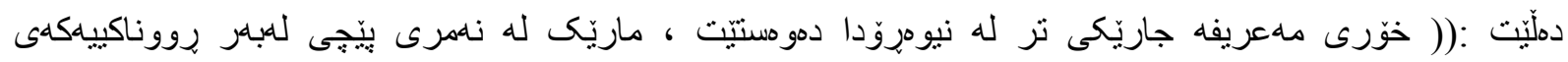

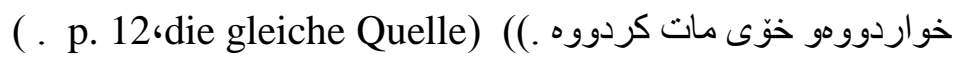

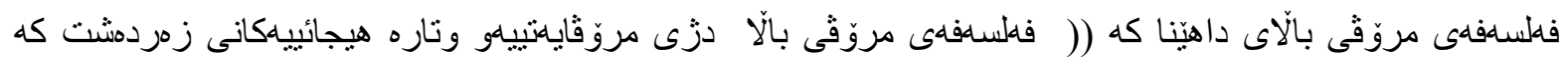

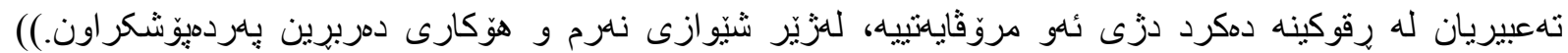

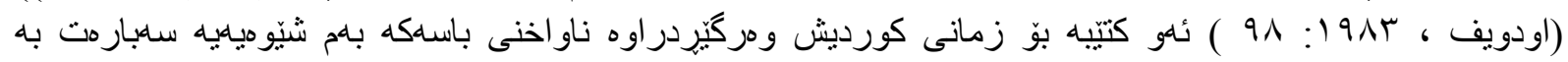

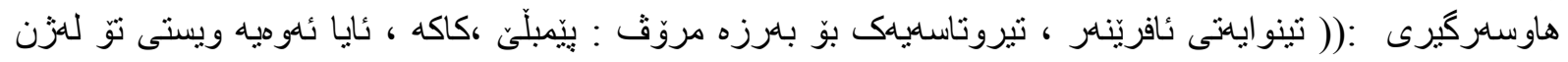

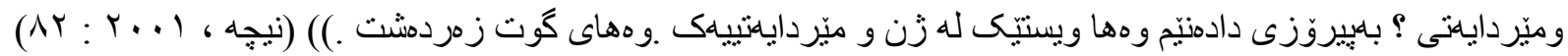

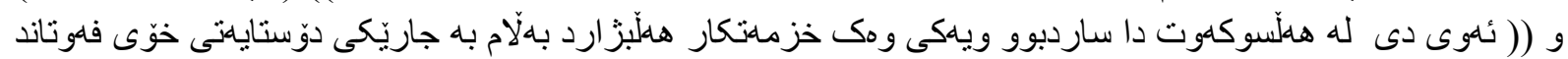

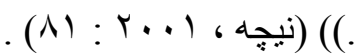

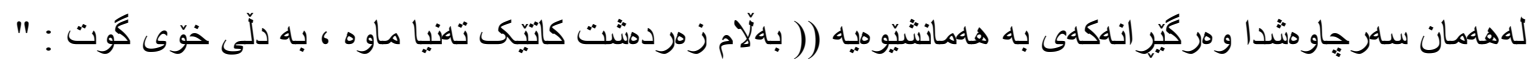

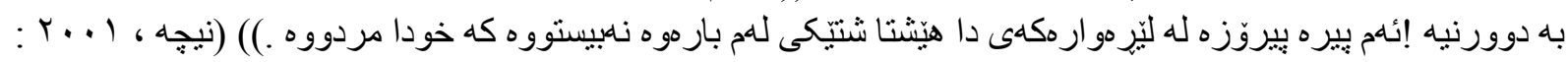

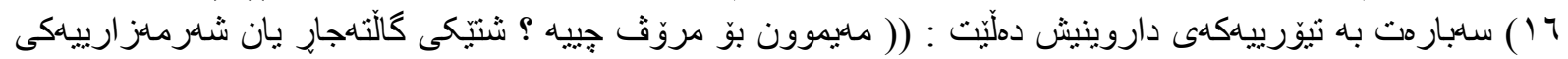

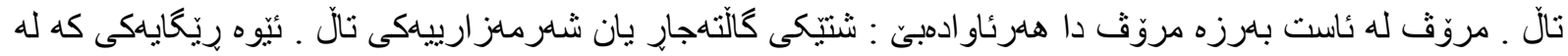

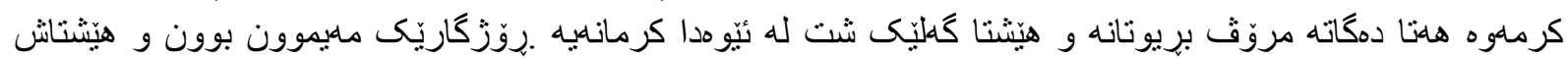

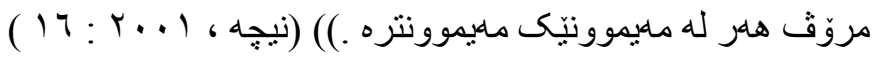

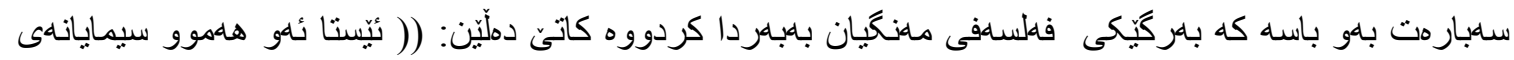

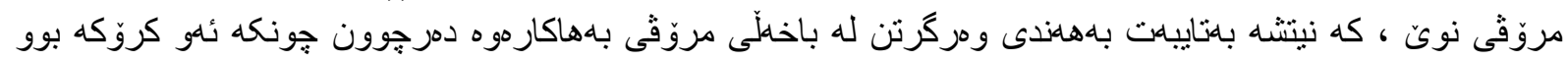

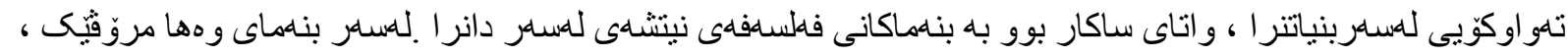

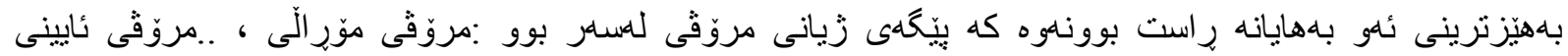

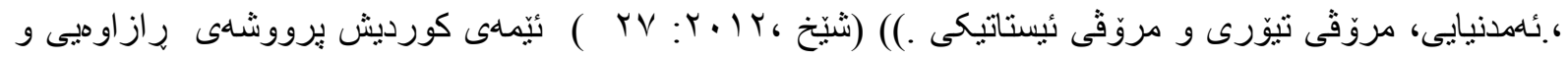

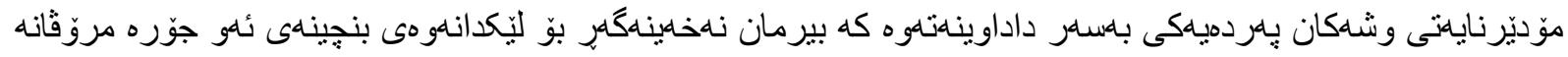

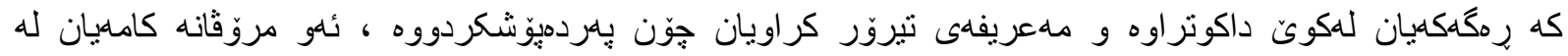

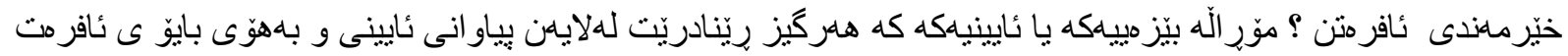

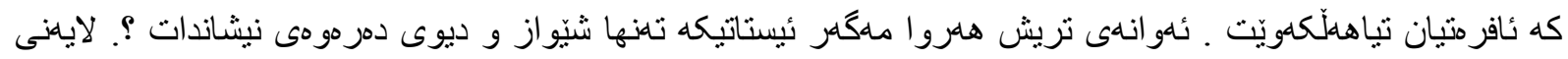

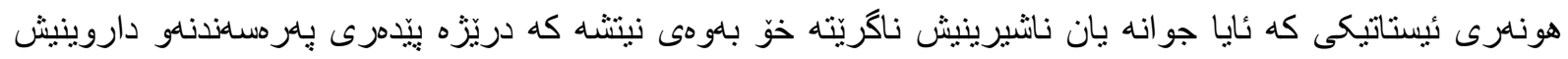

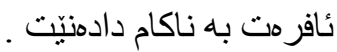

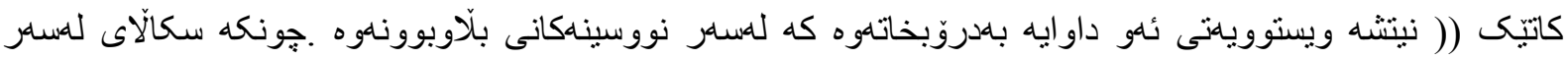

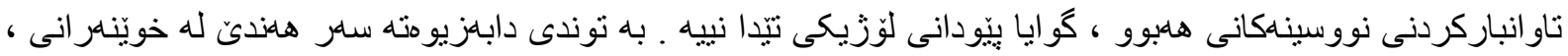

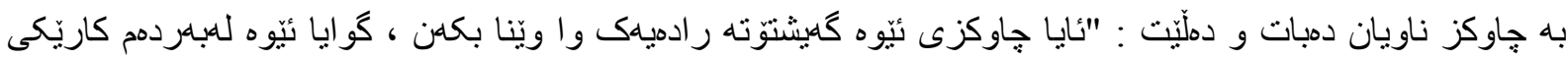

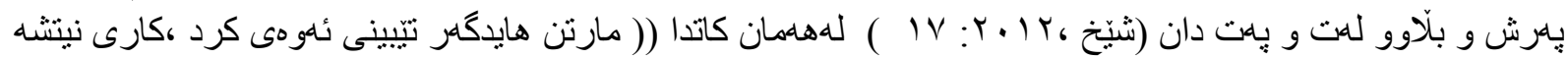

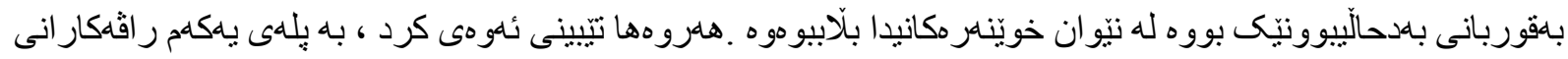

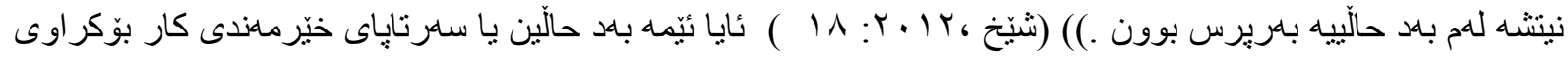

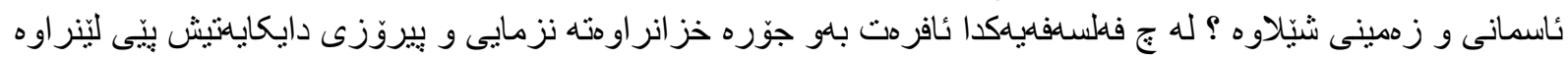

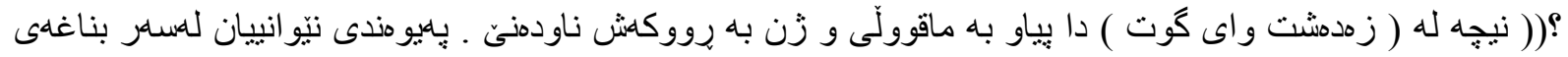

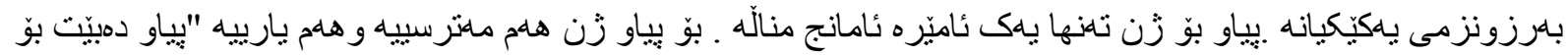

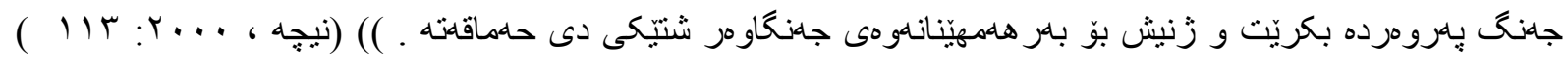

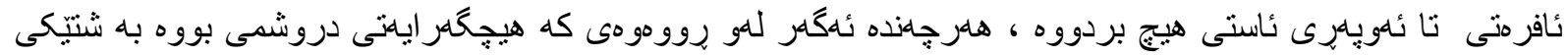

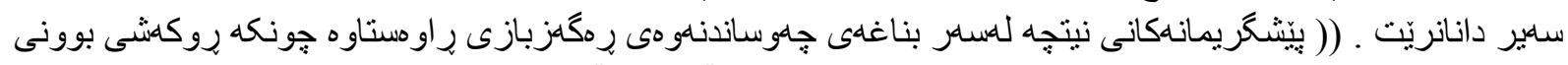

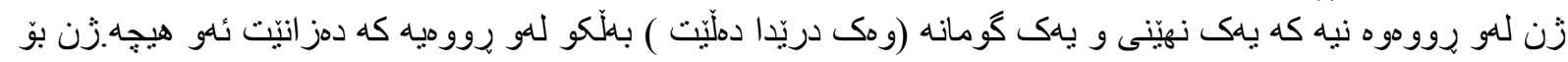

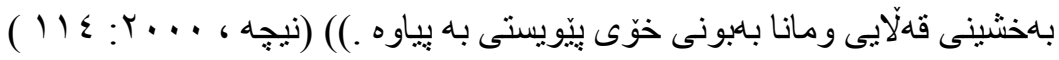




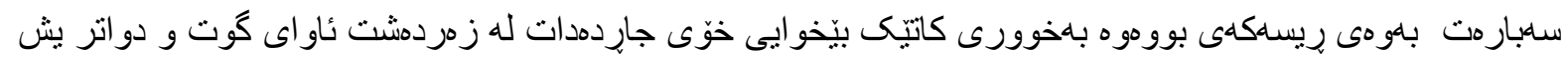

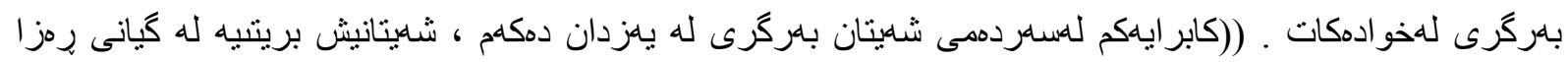

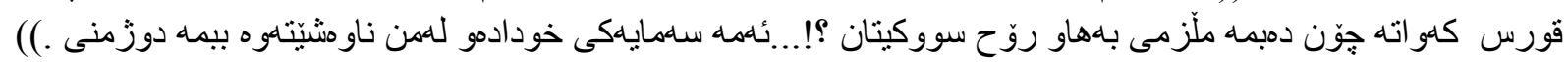

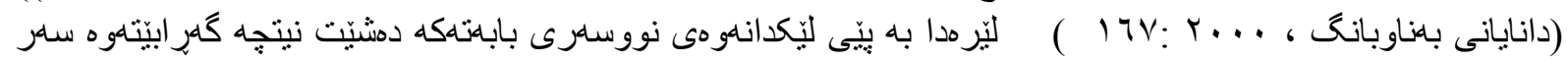

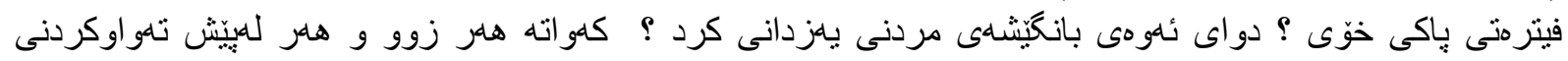

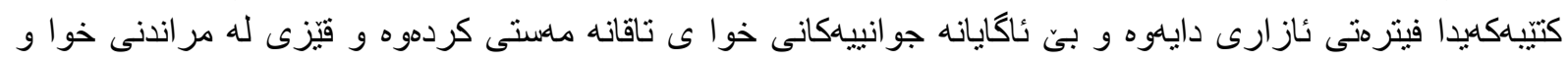

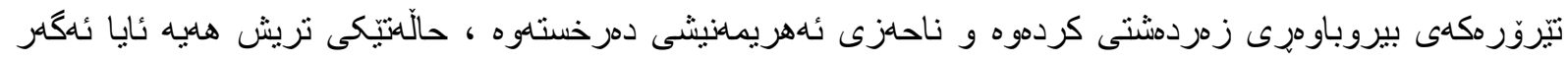

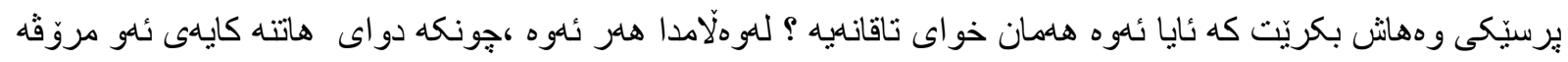

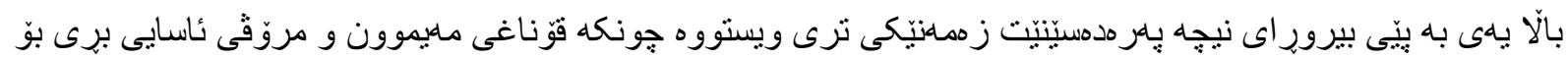

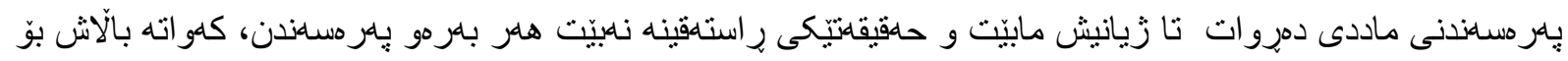

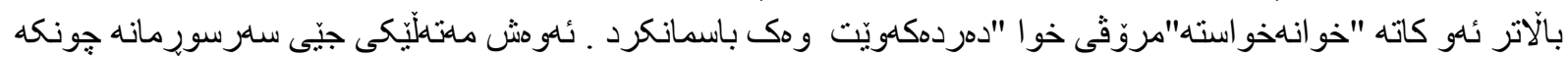

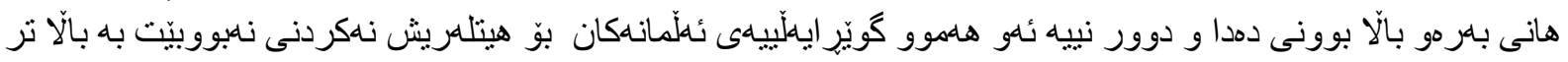

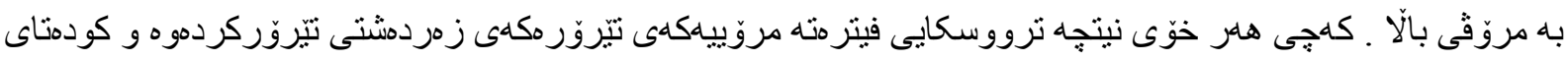

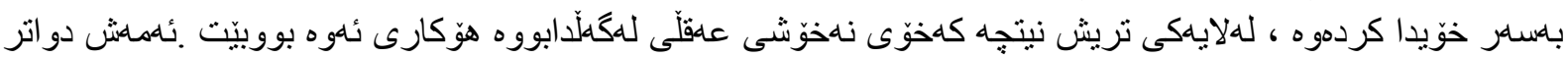

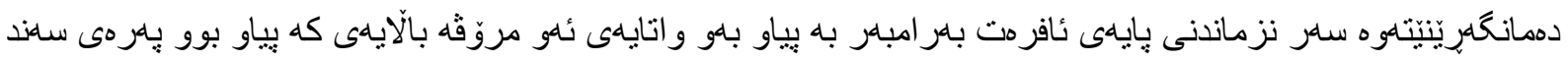

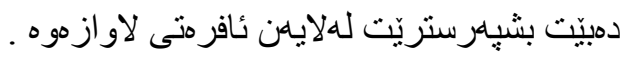

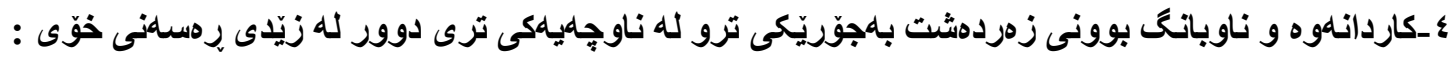

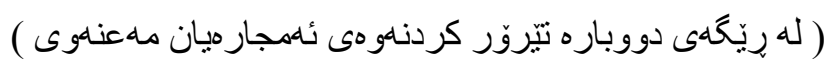

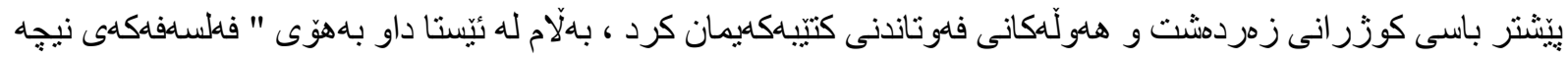

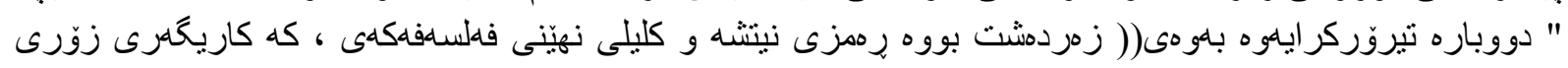

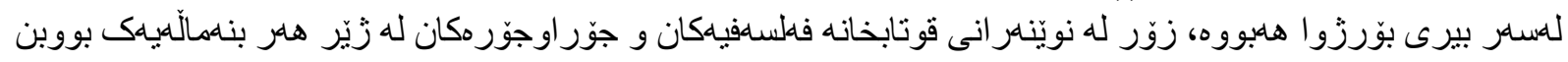

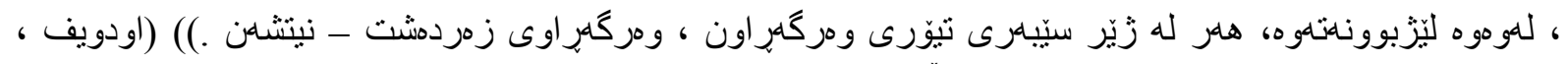

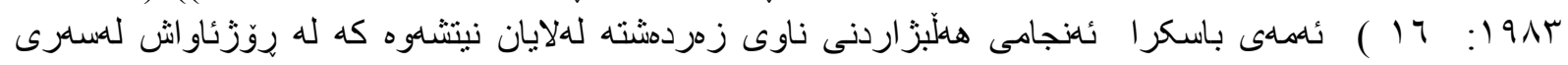
نووسراوه.

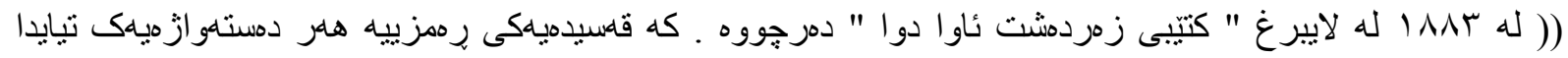

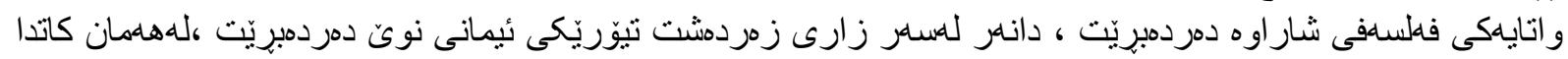

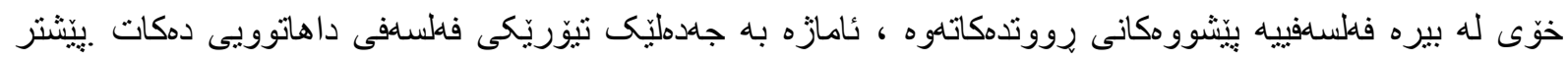

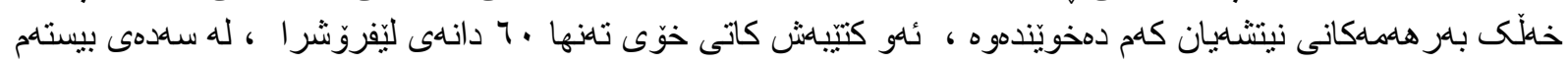

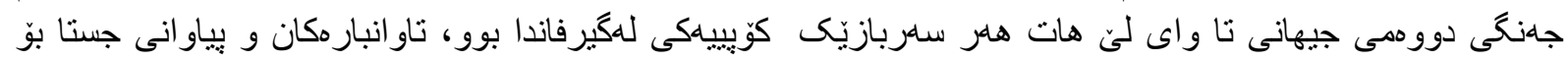

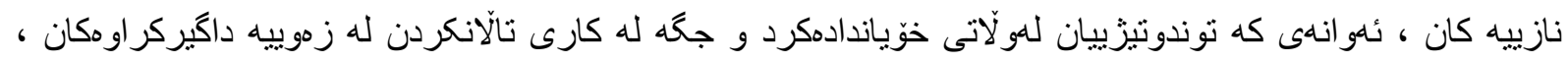

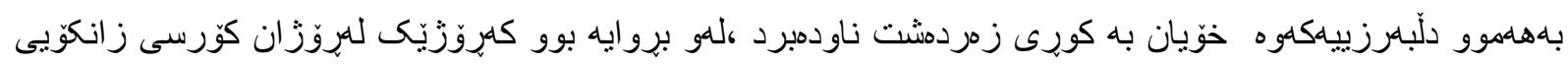

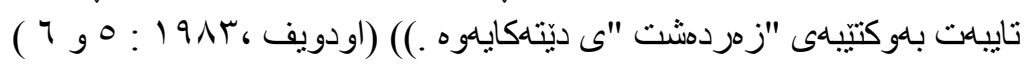

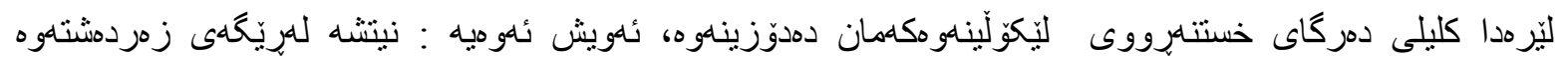

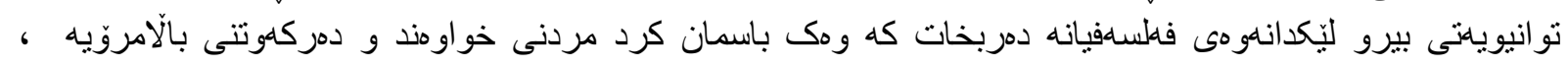

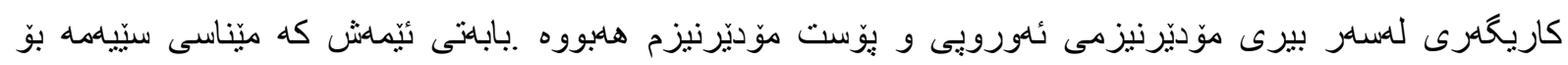

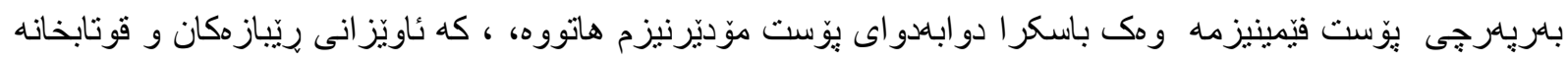

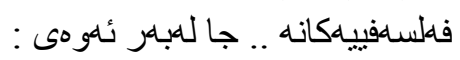




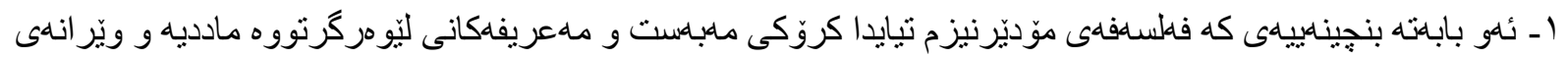

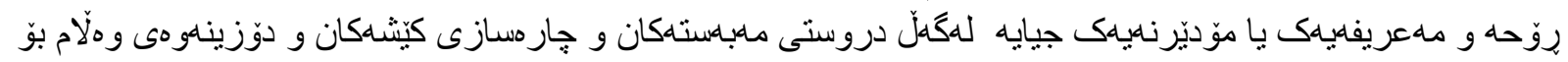

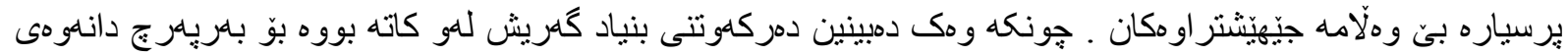

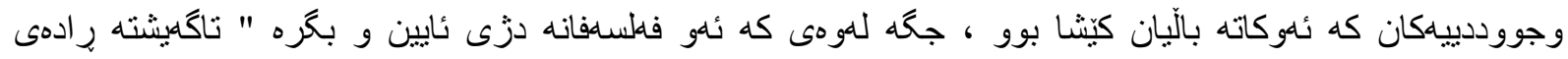

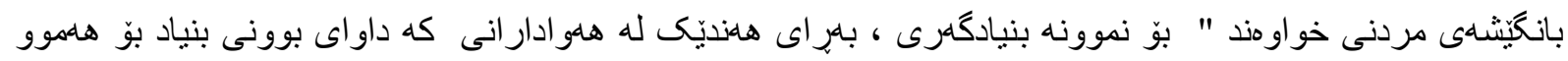

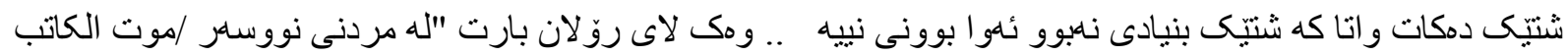

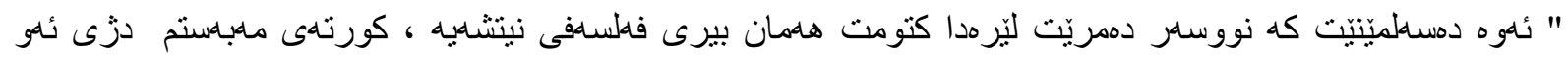

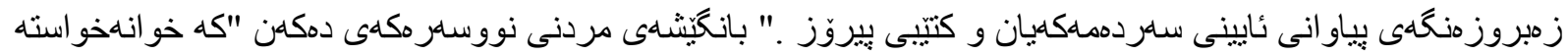

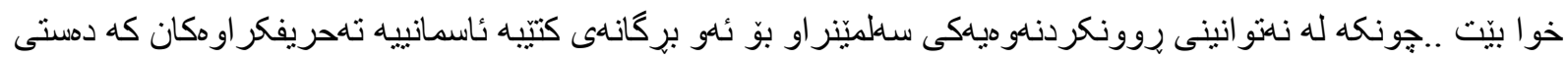

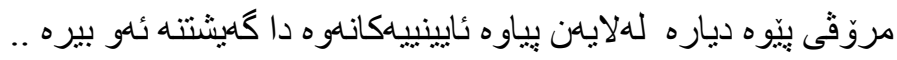

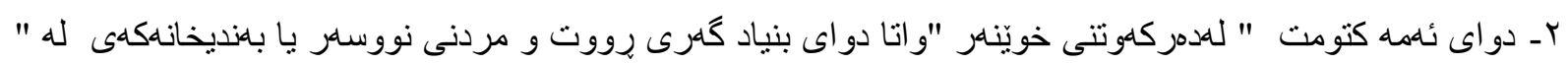

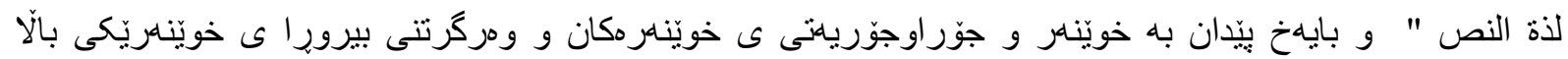

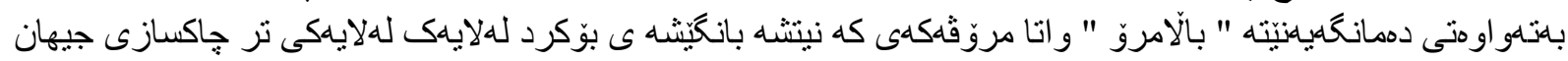

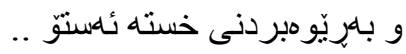

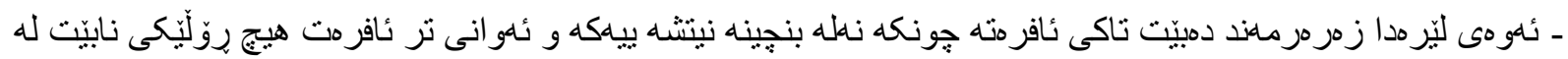

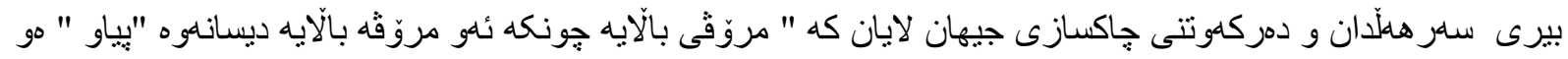

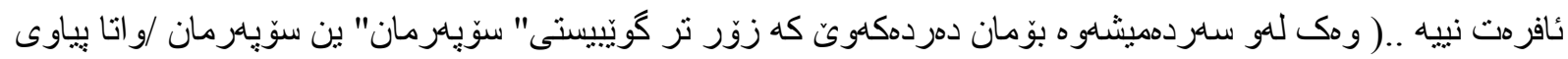

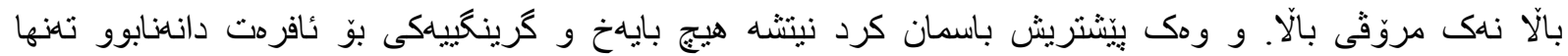

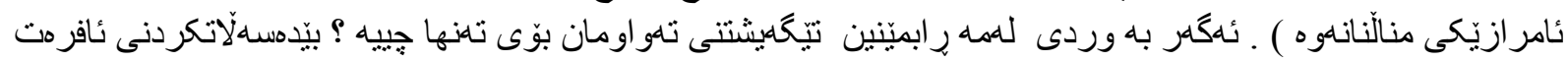

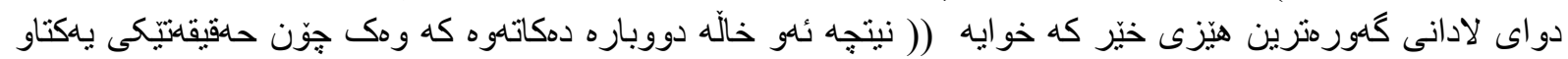

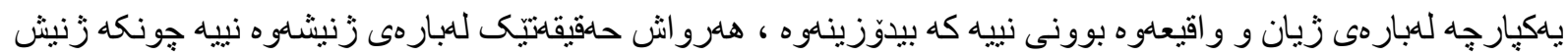

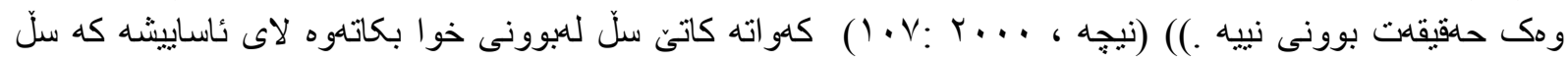

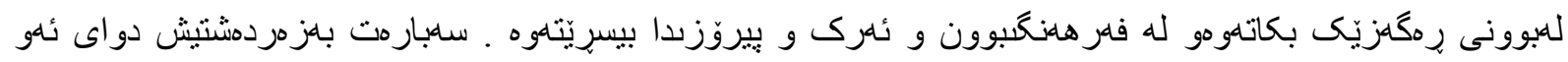

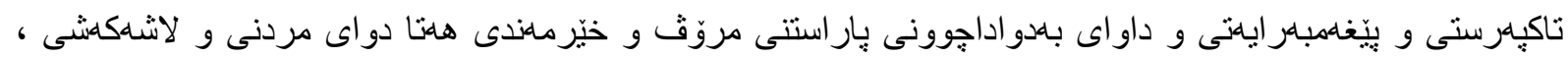

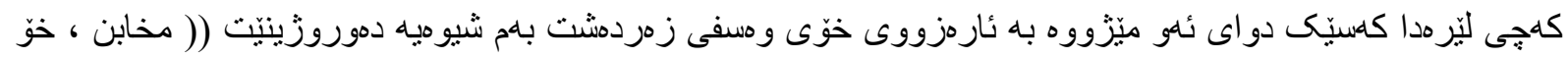

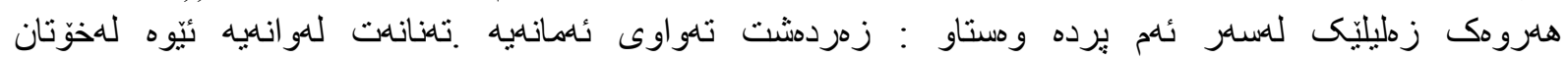

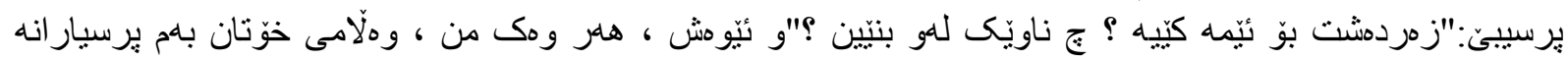

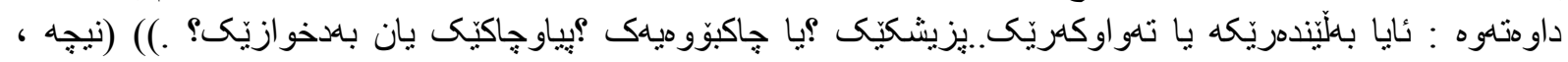

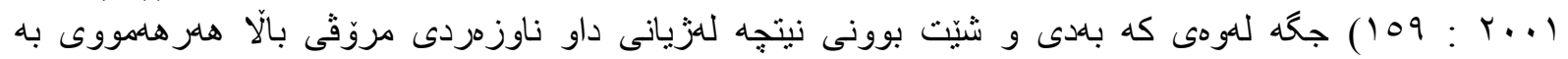

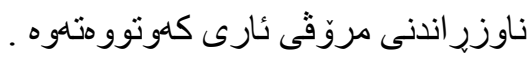

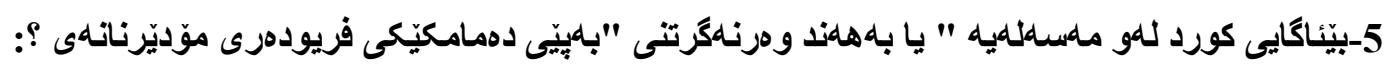

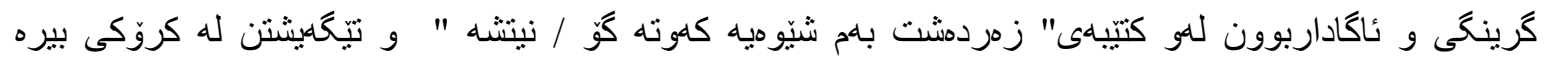

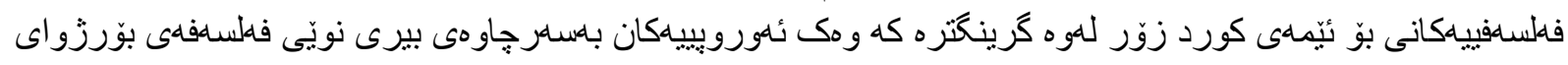

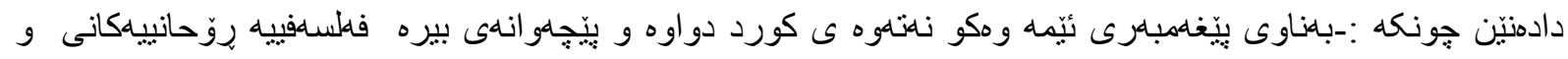

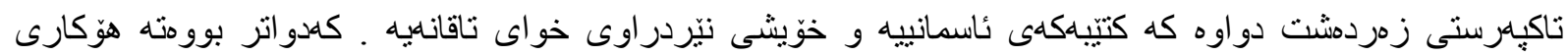

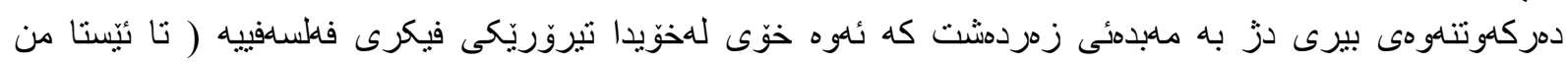

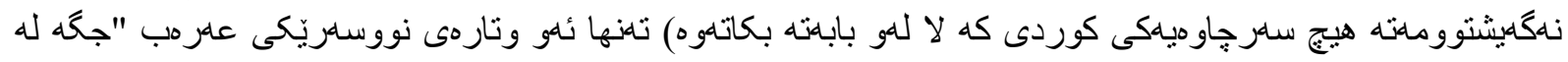

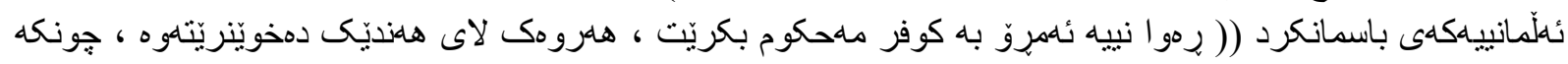

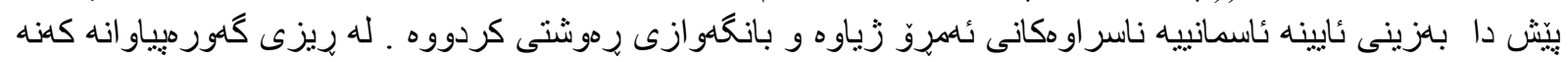




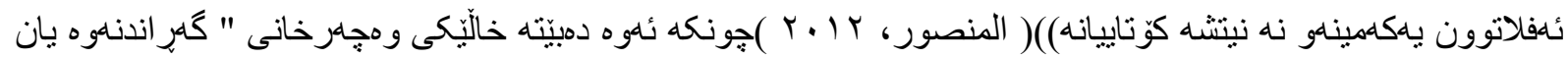

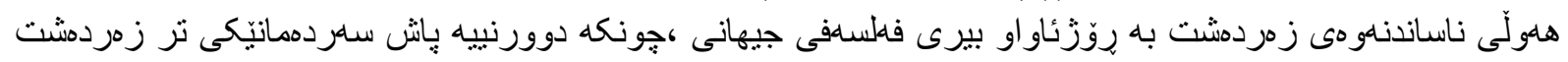

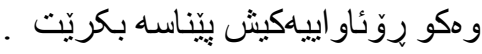

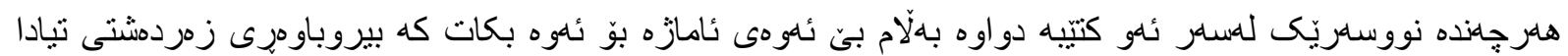

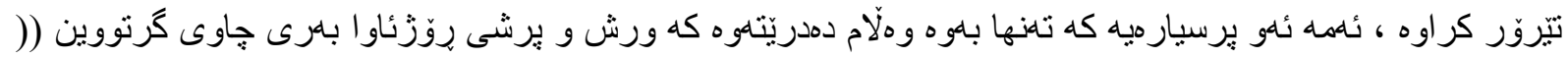

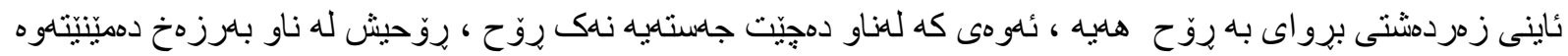

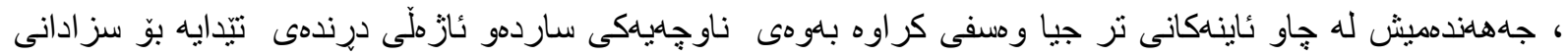

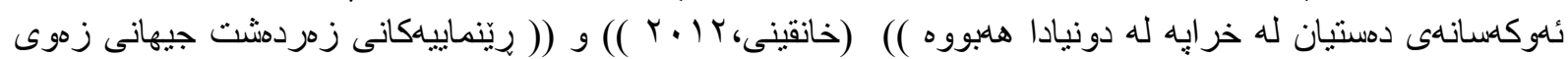

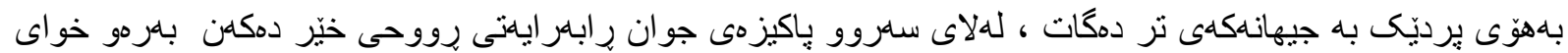

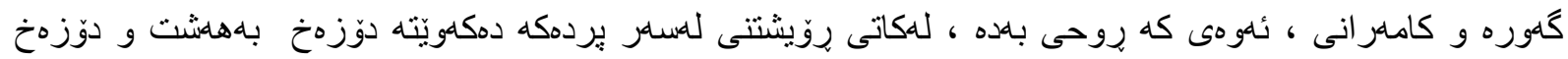

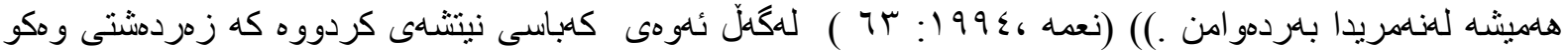

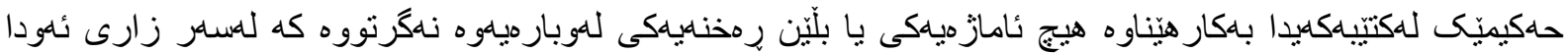

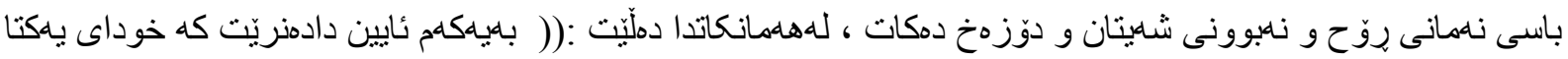

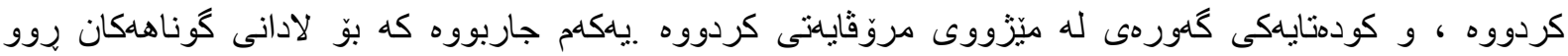

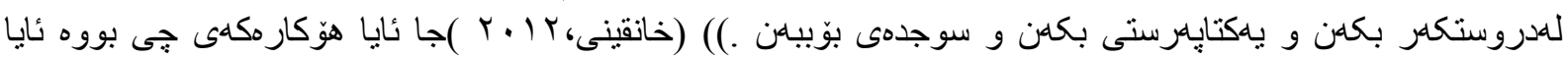

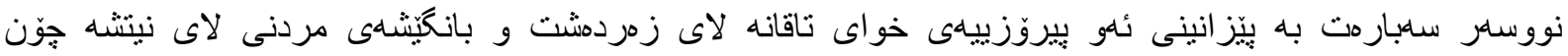

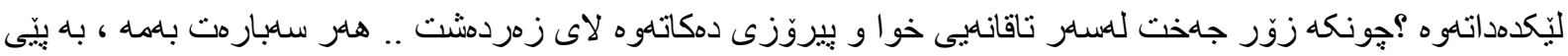

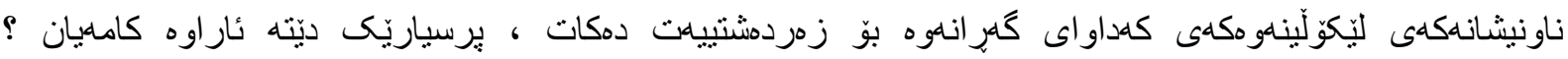

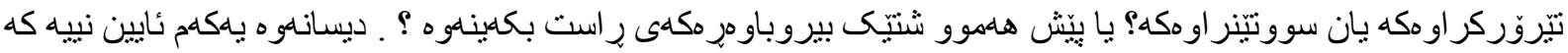

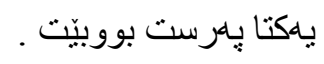

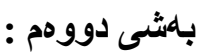

زمردشتنتئى و مهلاى كاهوره :

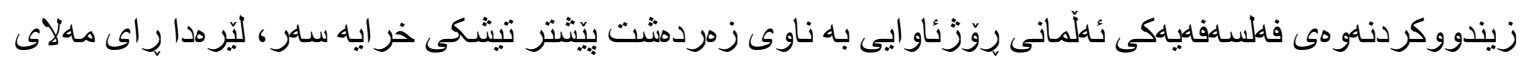

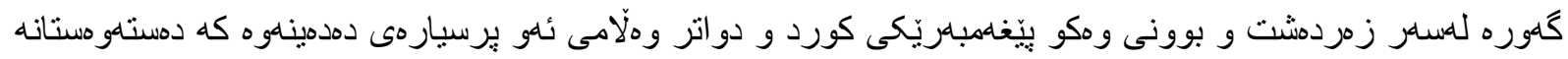

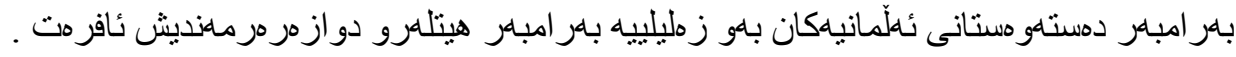

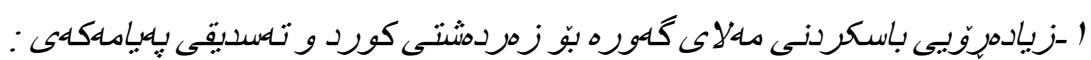

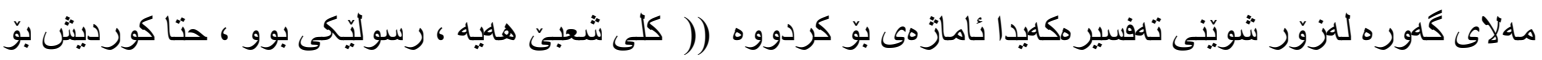

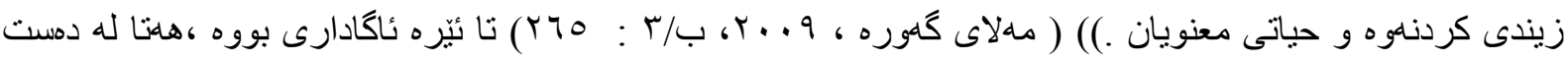

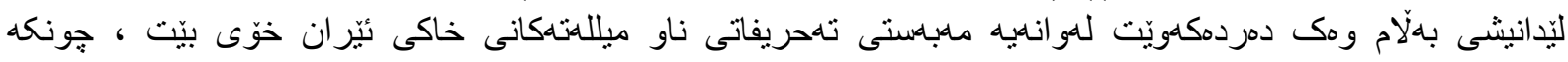

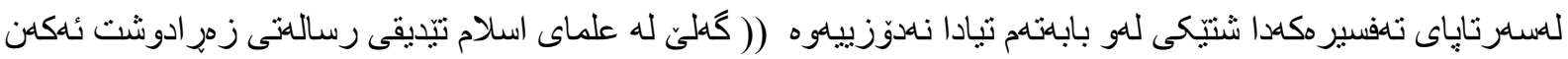

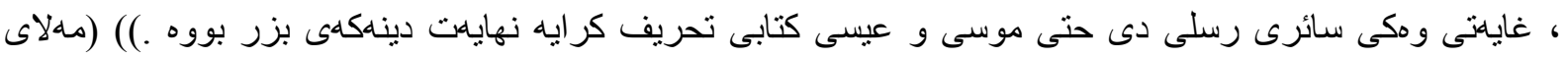

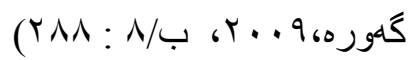

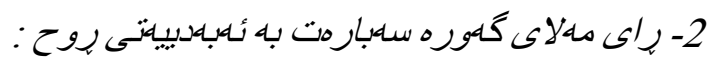

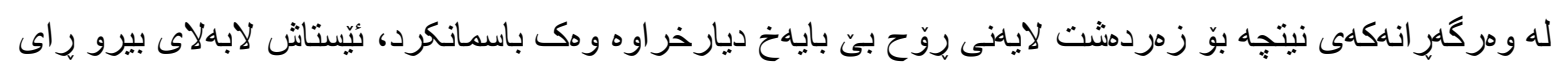

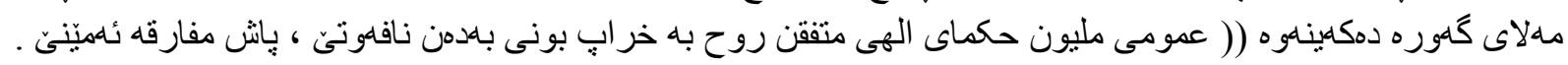




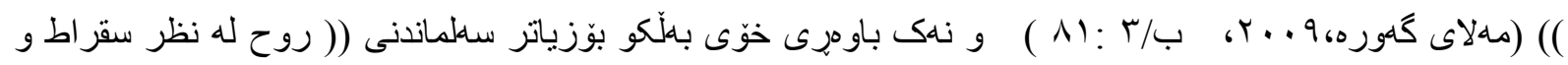

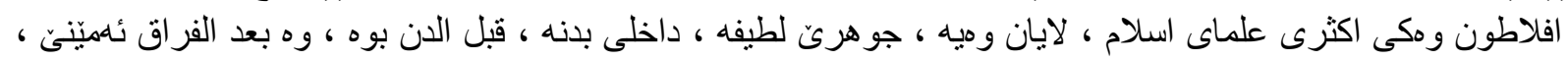

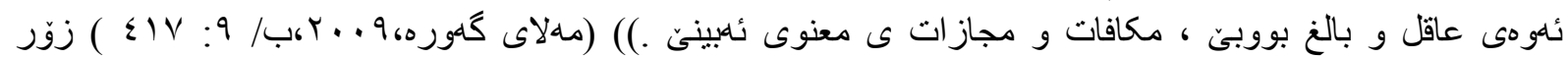

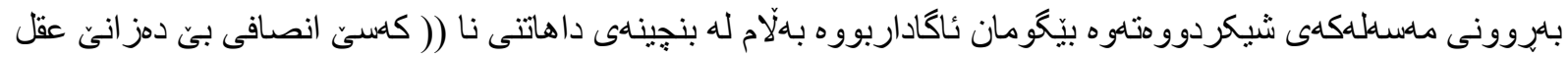

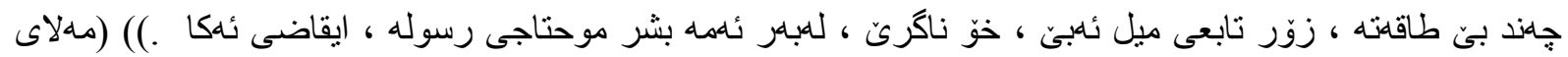

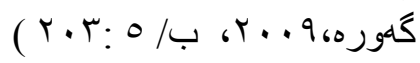

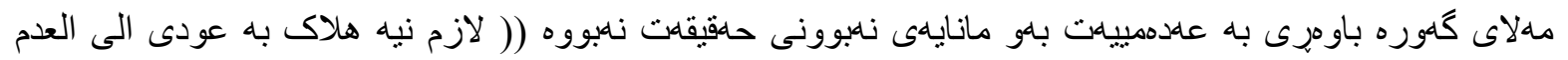

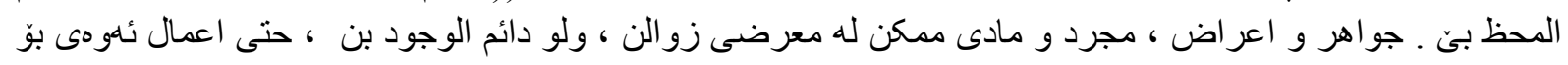

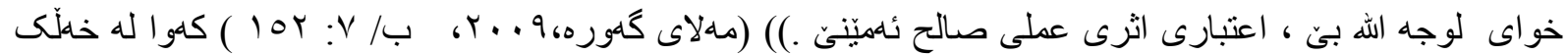

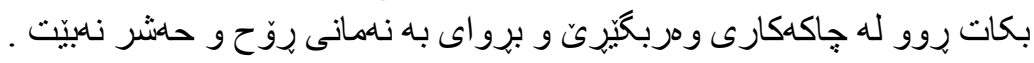

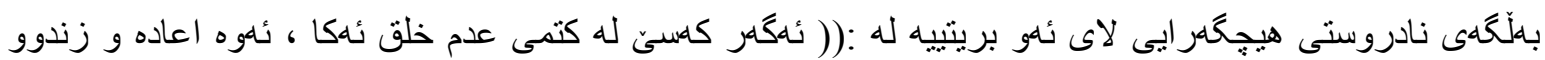

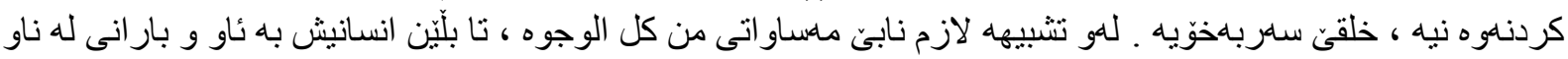

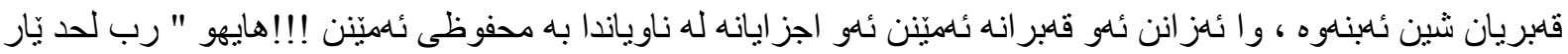

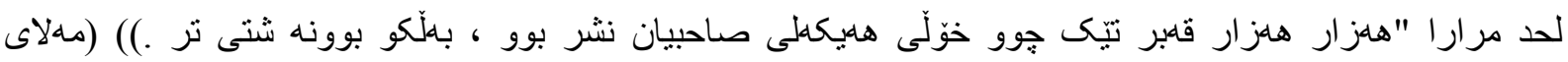

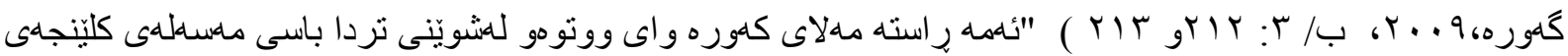

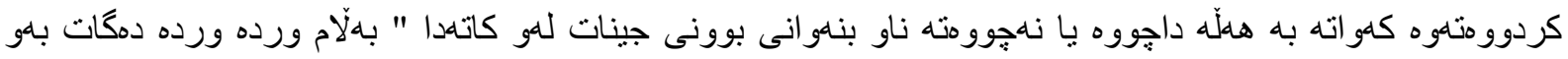

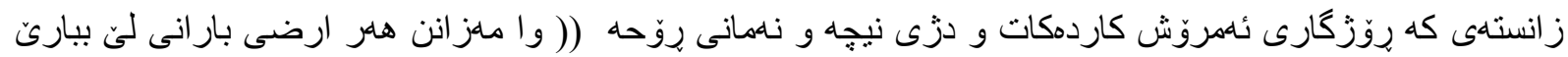

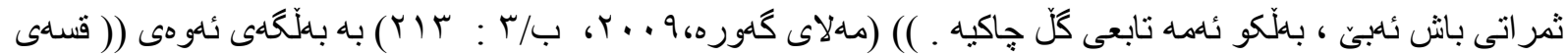

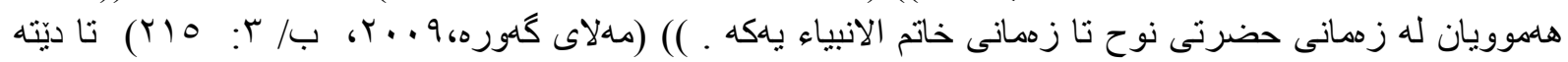

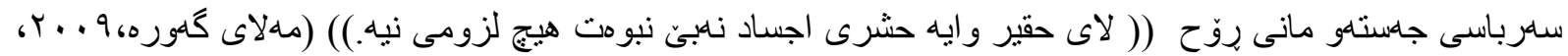

( IV 1 :

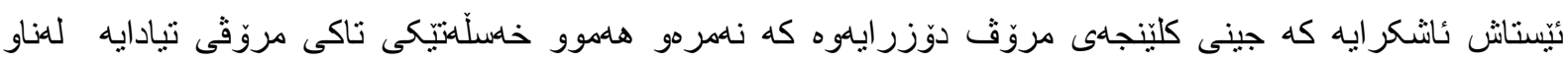

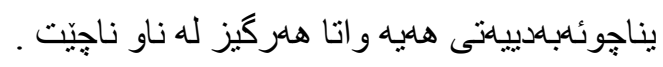

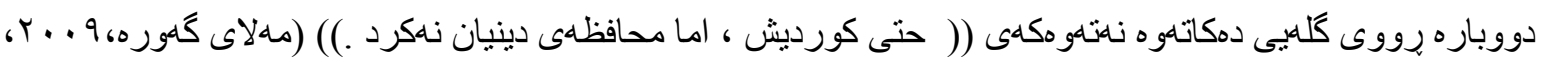

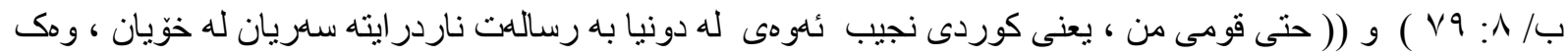

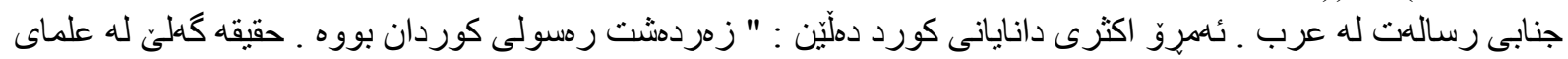

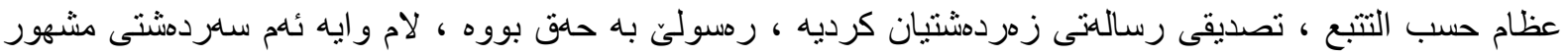

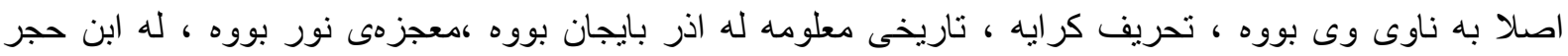

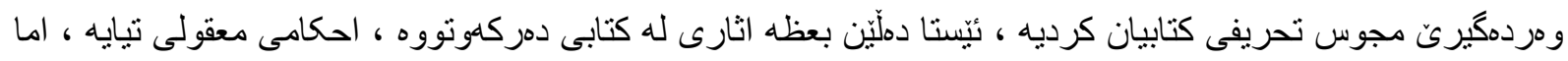

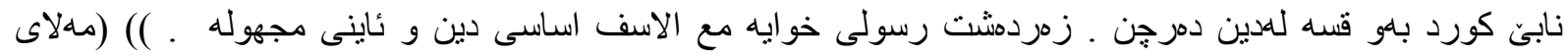

(IVT:

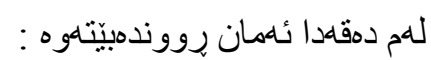

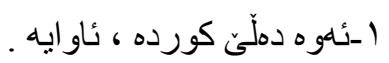

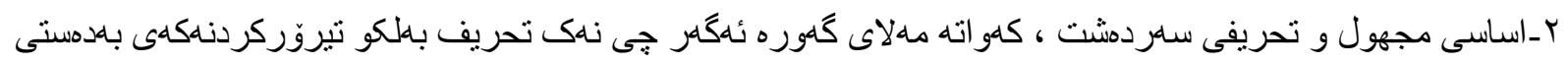

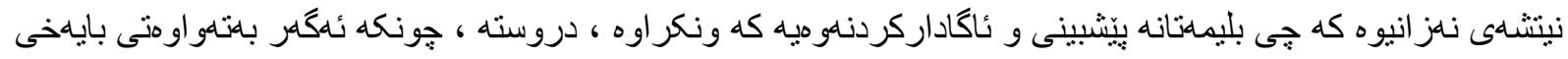

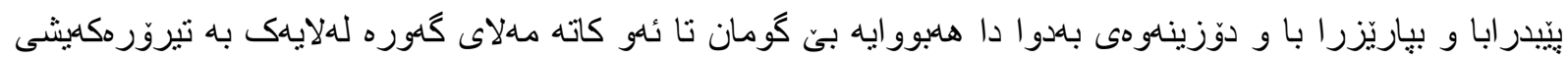

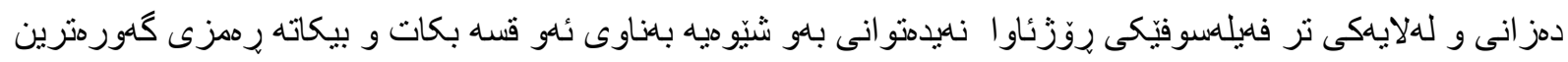

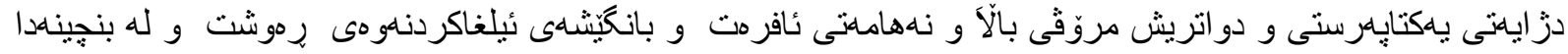

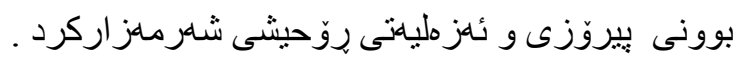




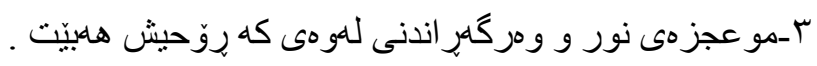

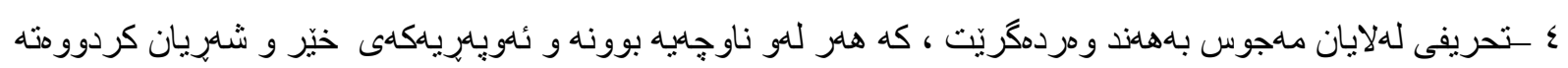

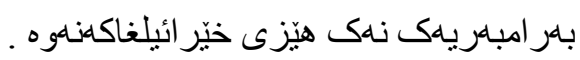

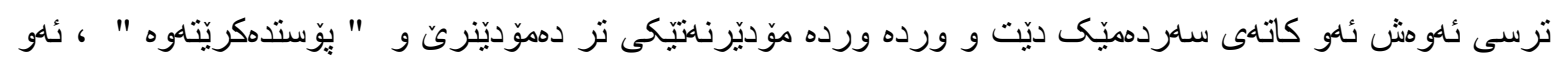

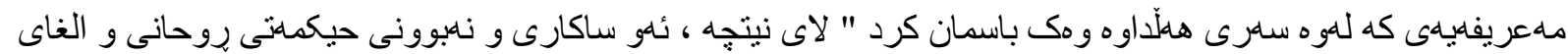

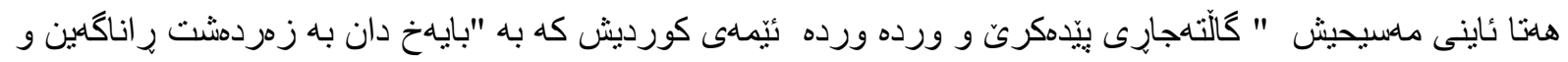

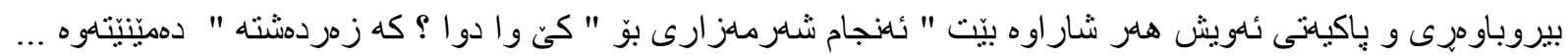

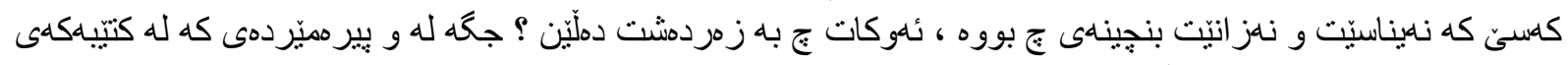

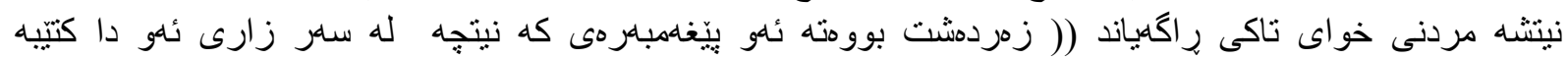

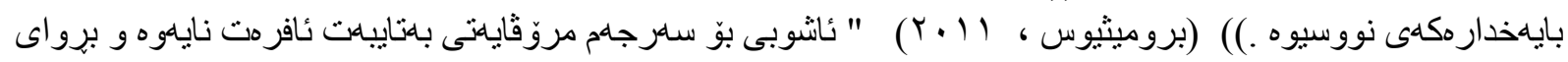

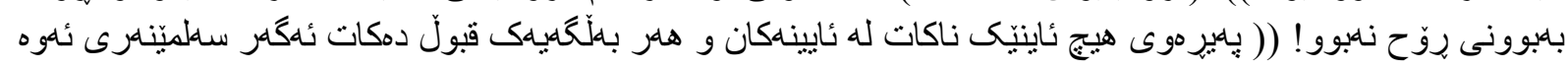

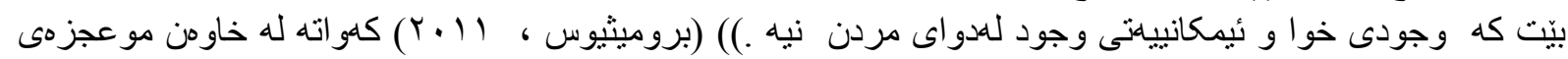

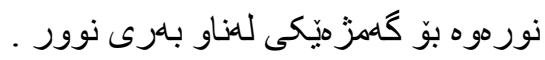

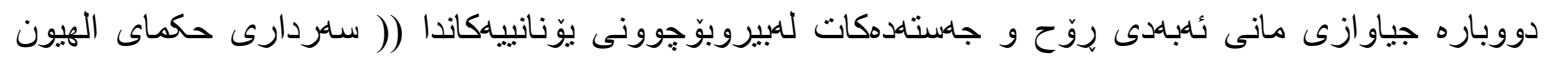

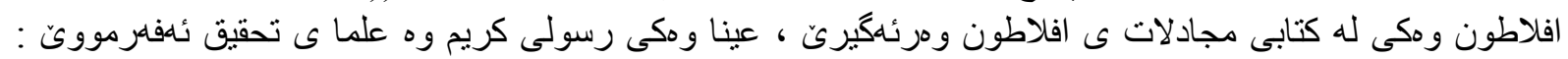

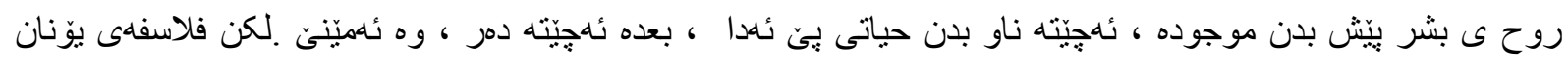

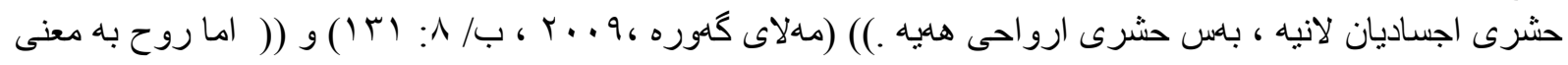

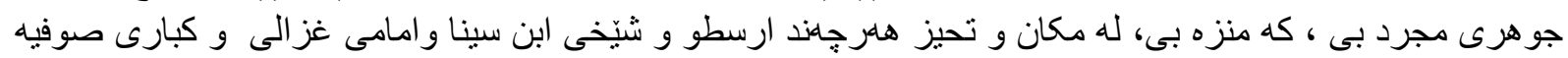

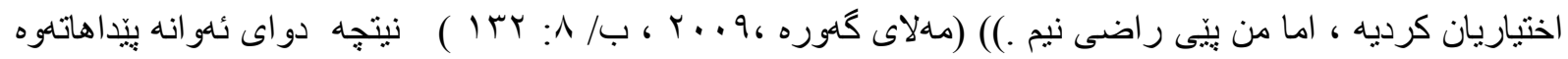

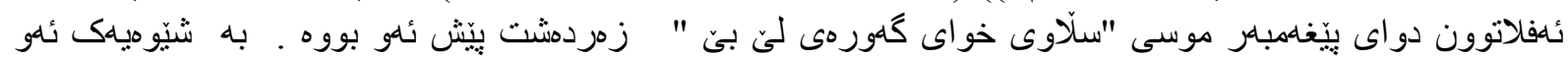

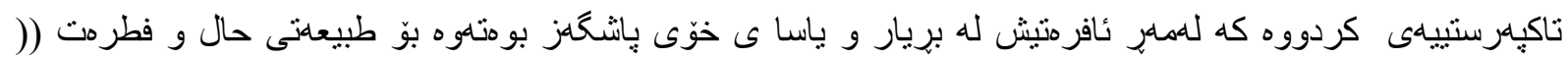

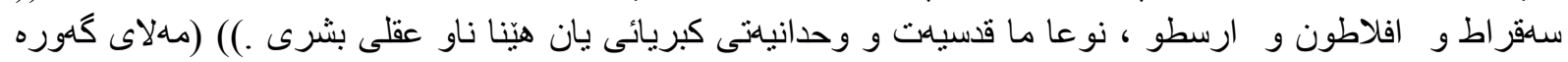
$(v \cdot \varepsilon:) \cdot \varphi$ ، r...9،

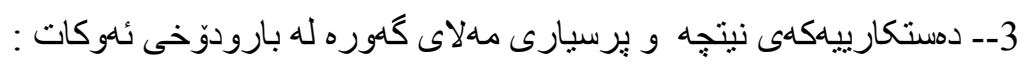

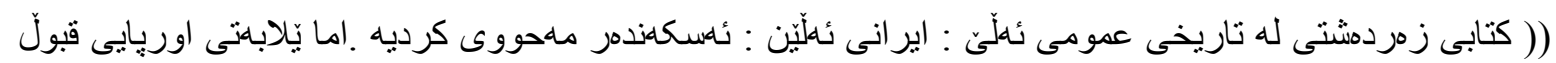

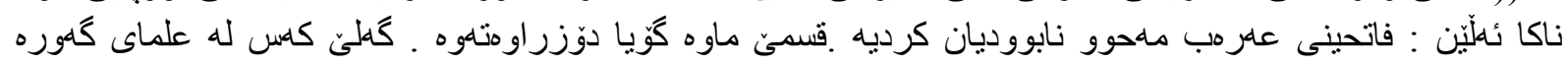

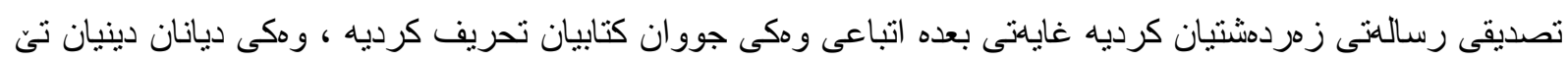

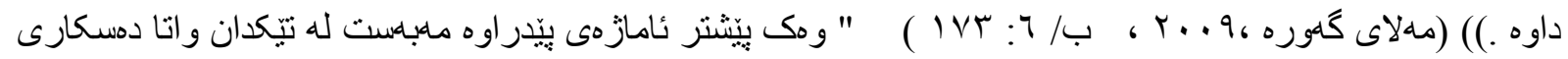

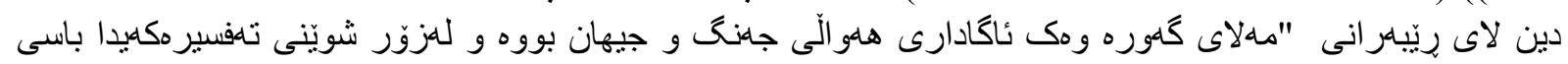

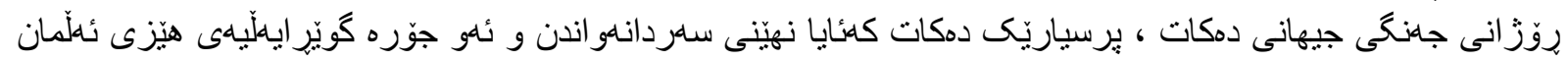

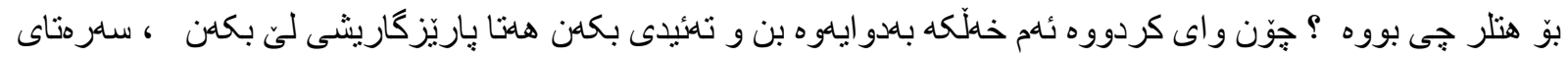

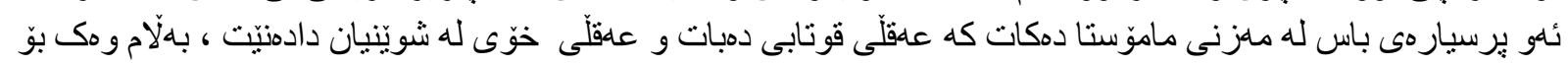

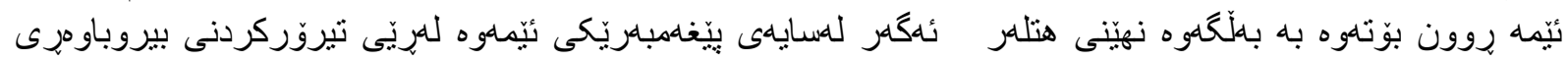

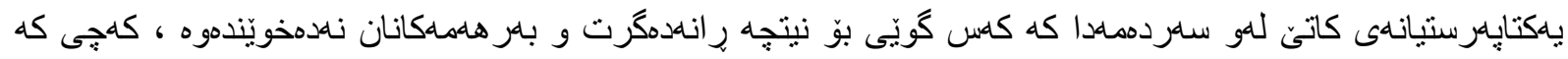

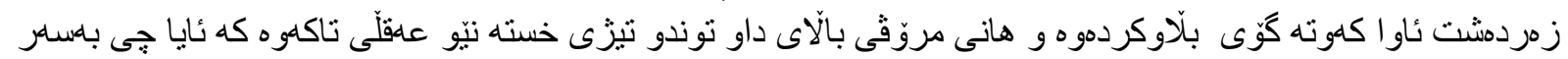

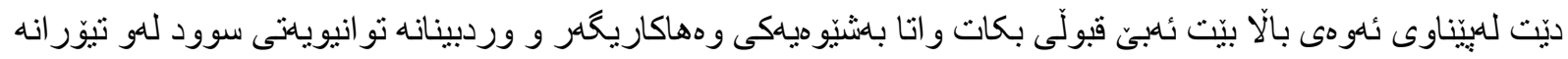

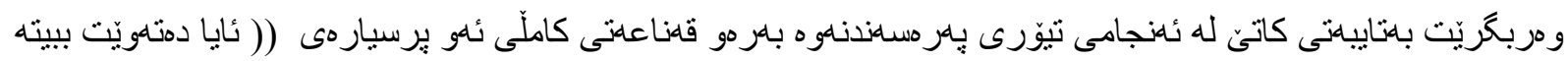

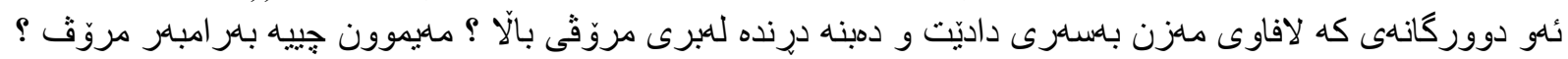

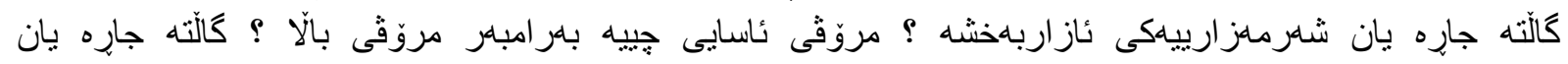

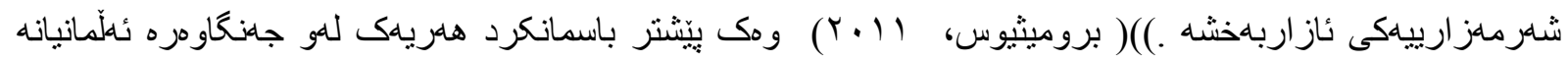




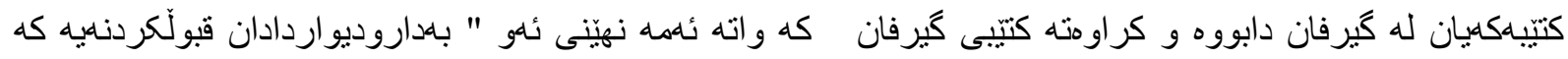

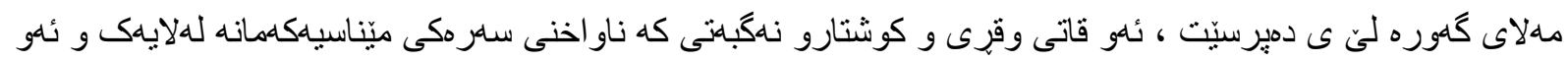

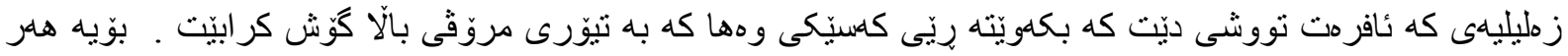

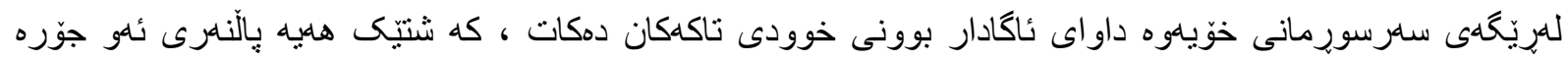

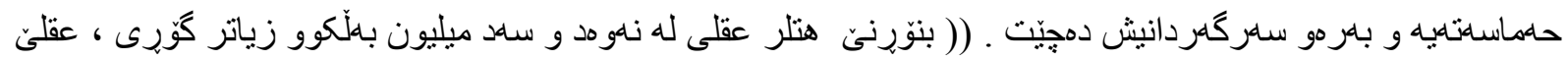

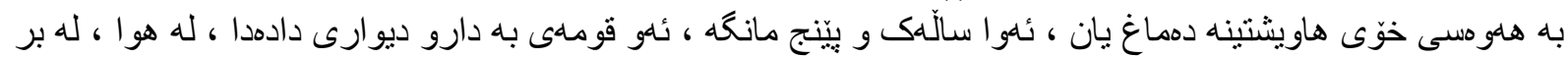

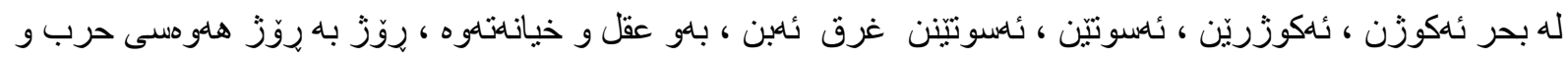

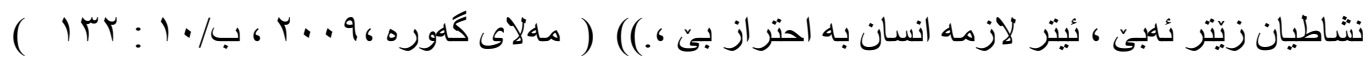

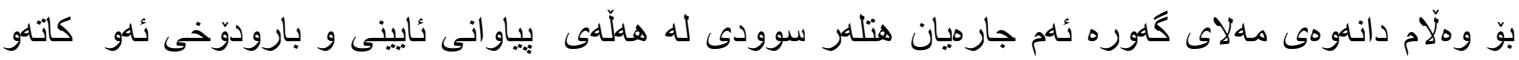

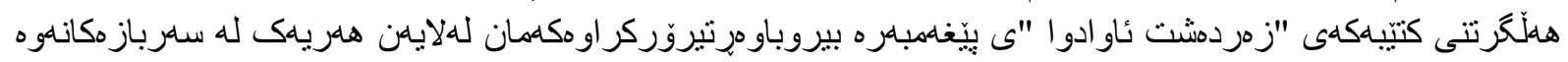

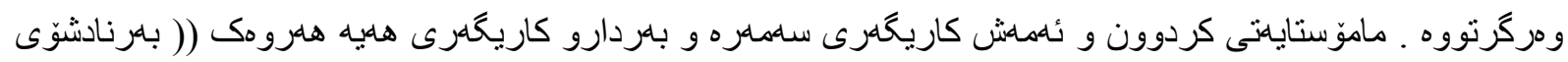

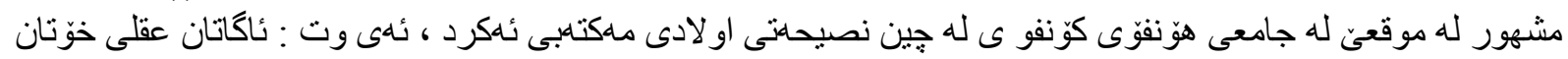

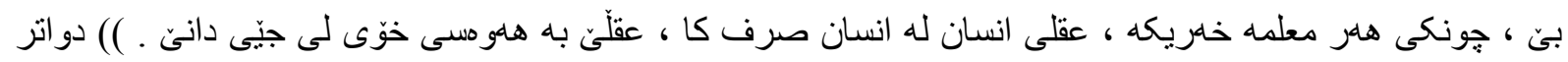

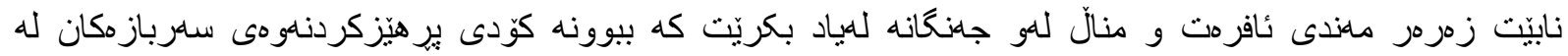

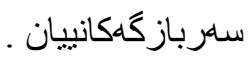

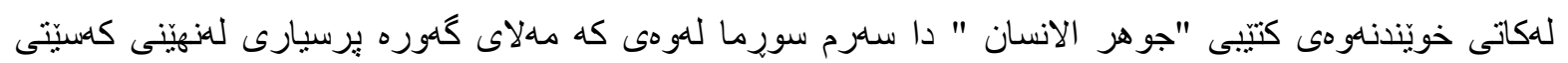

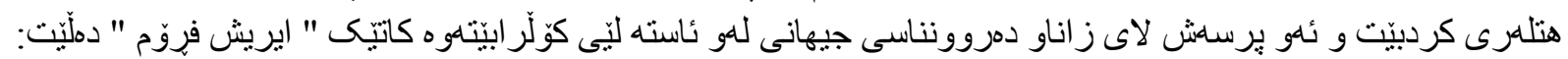

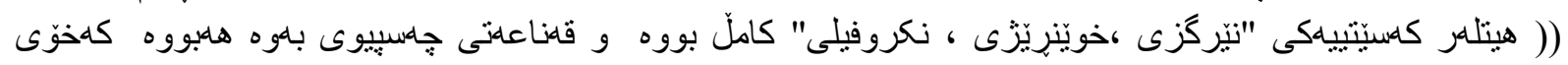

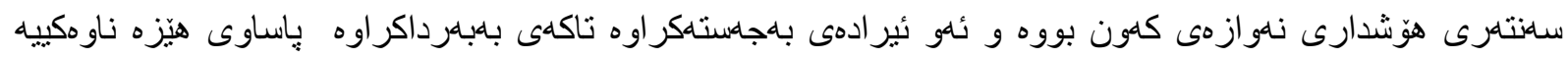

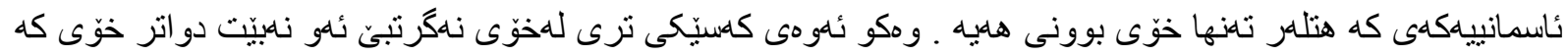

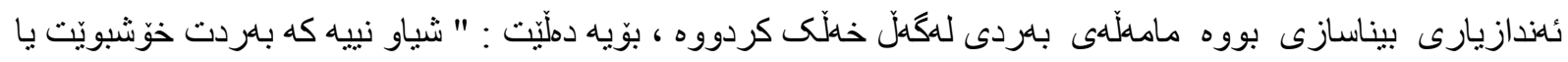

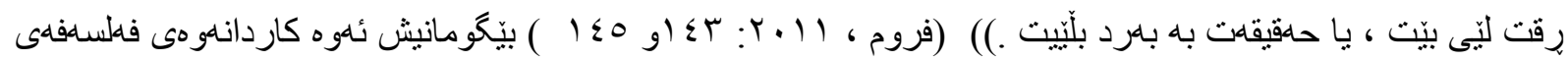

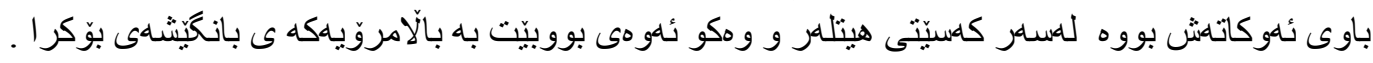
4- بالآيانتى بيهاو و زمليللى ئافرهت و دايكايهنى:

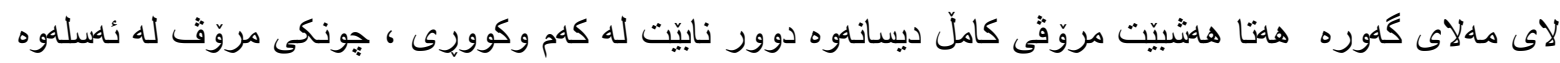

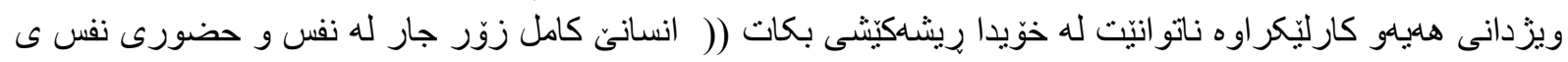

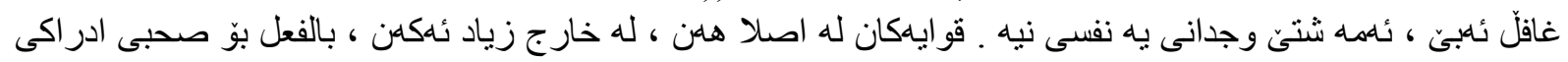

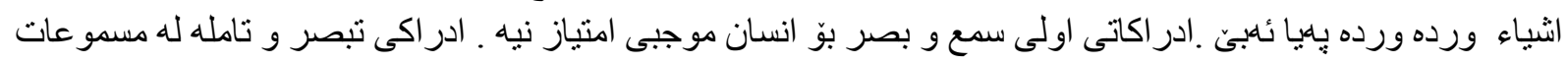

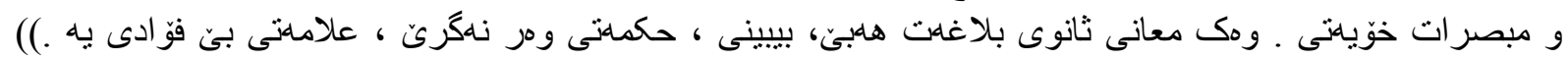

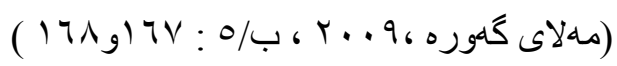

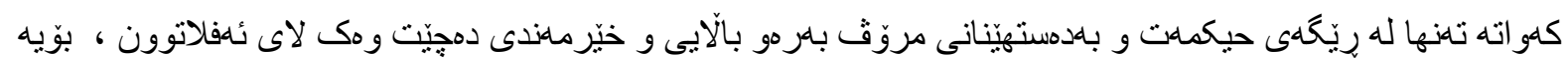

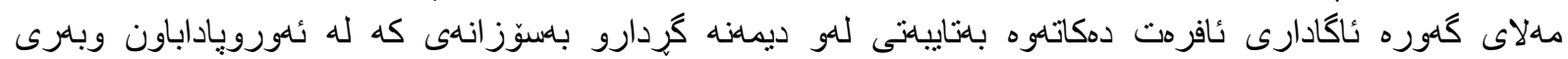

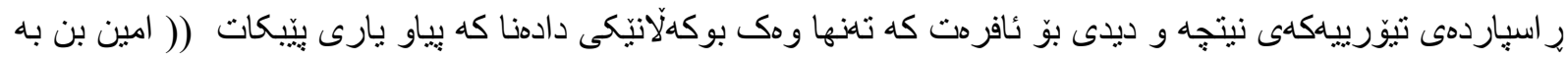

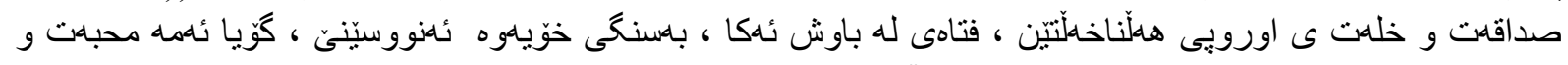

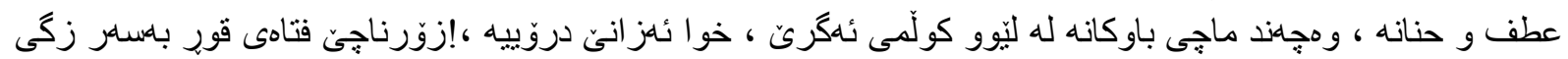

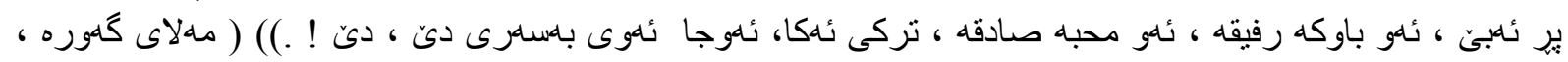

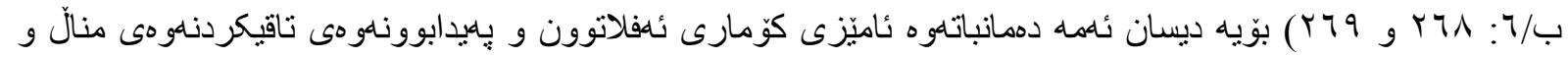

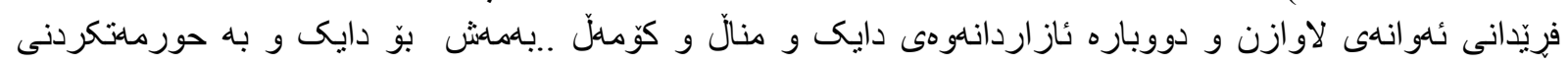

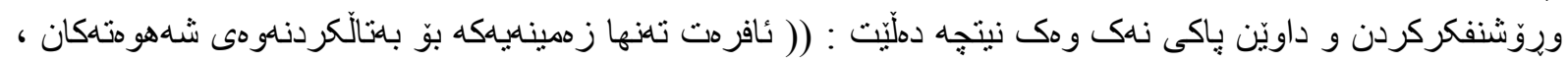

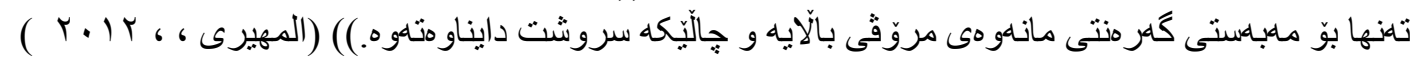




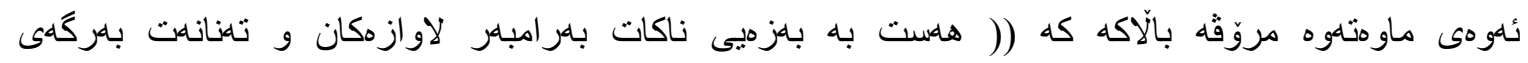

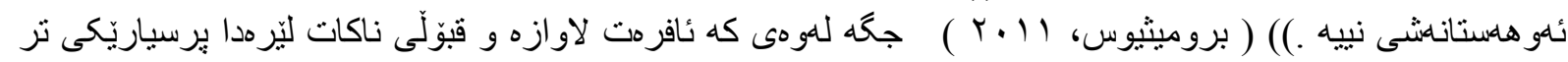

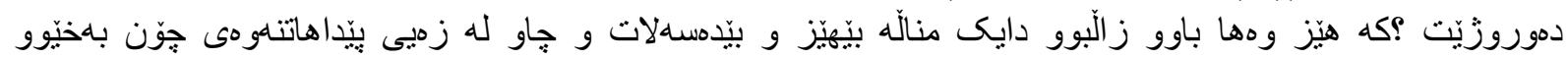

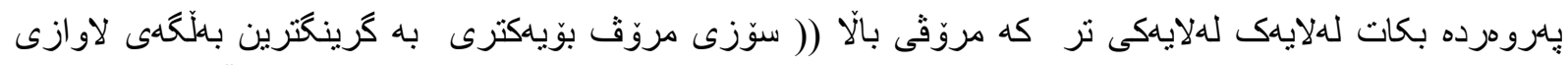

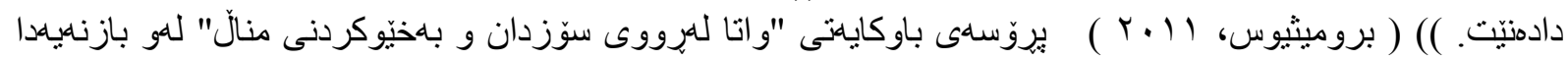

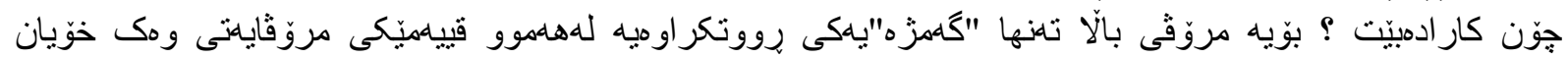

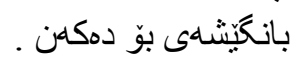

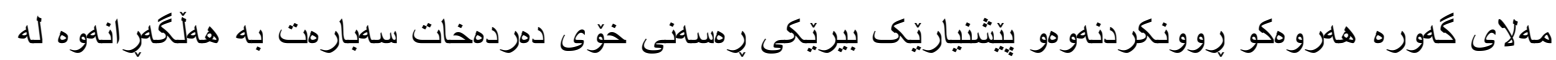

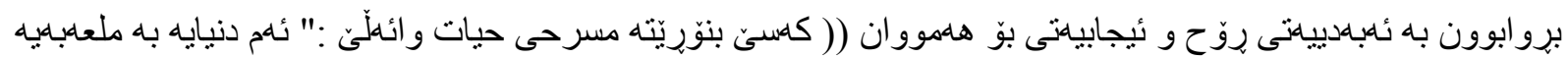

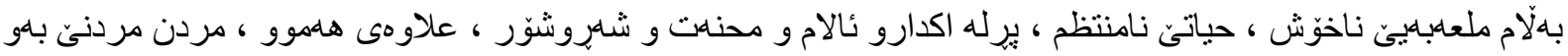

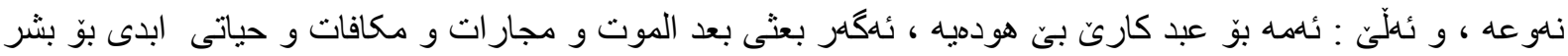

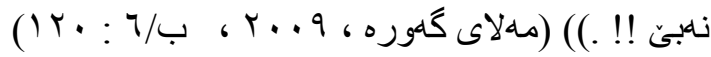

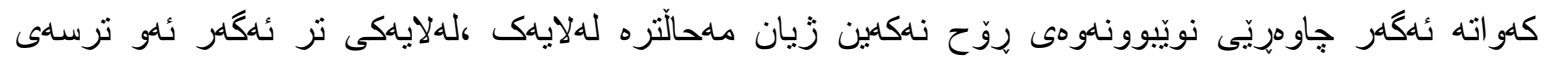

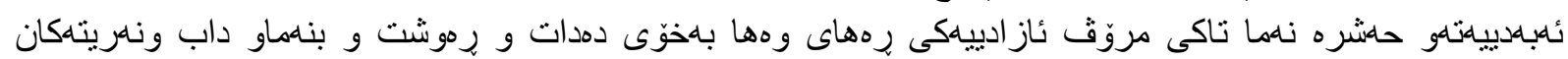

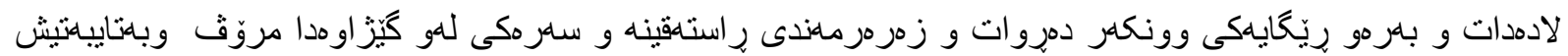

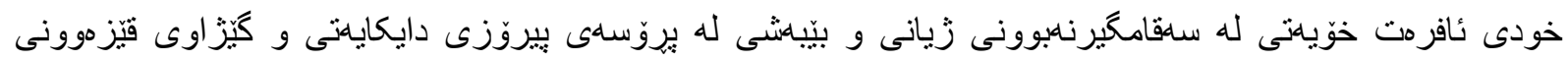

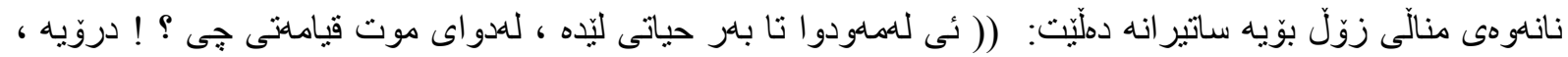

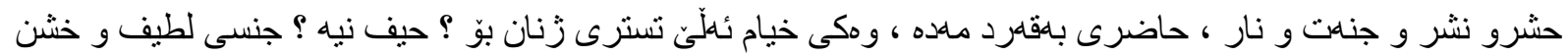

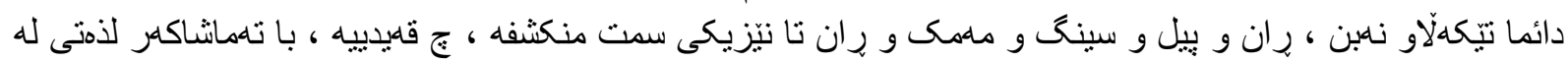

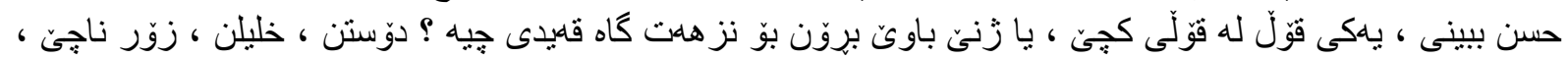

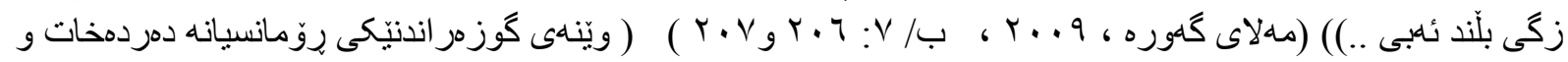

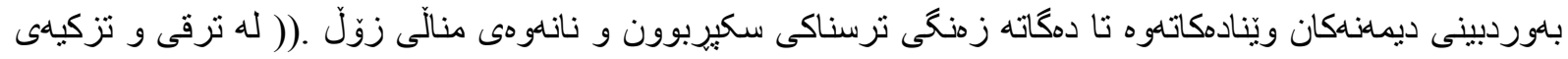

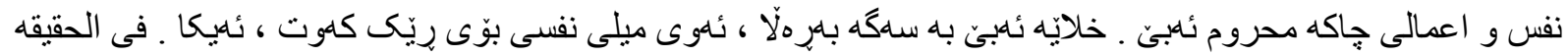

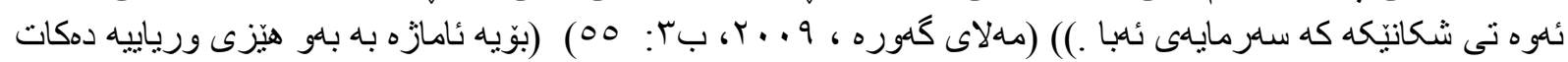

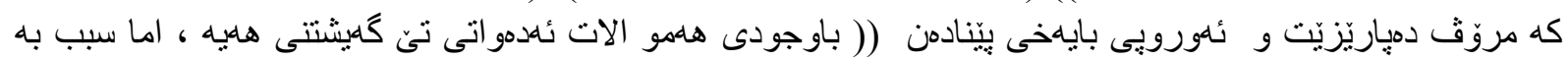

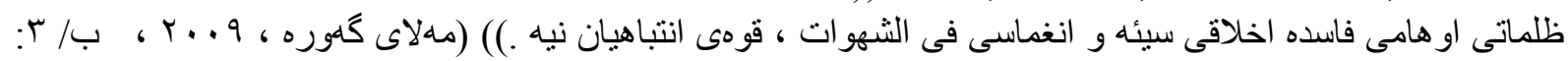

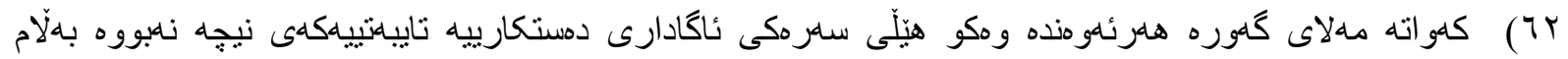

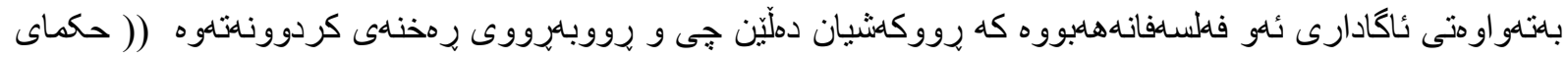

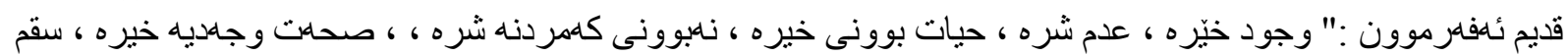

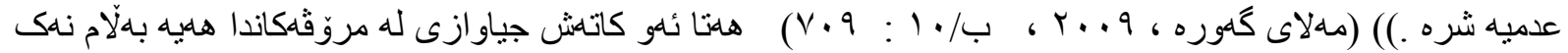

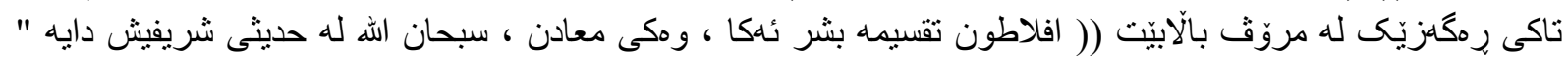

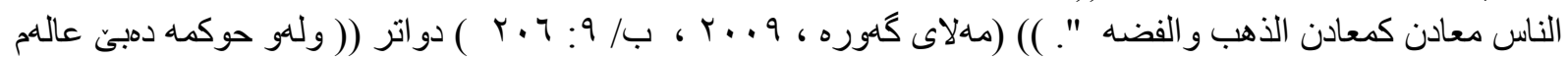

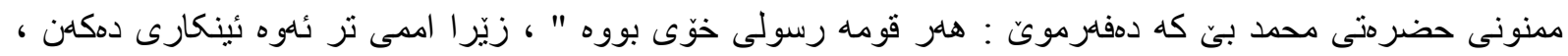

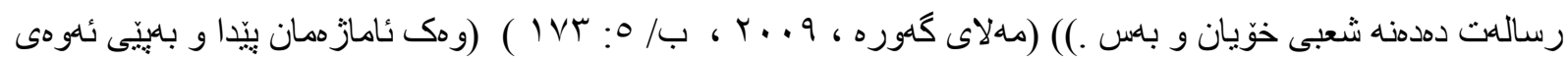

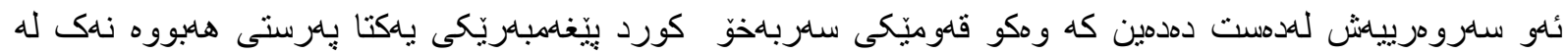

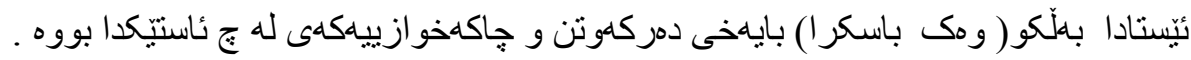

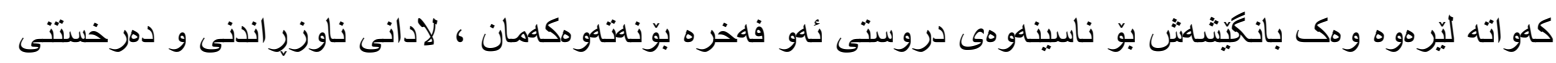

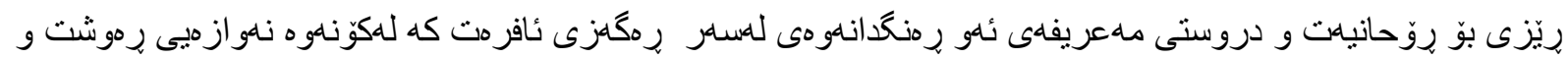

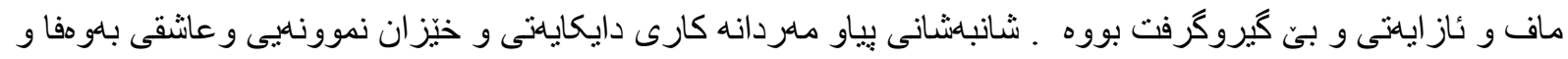

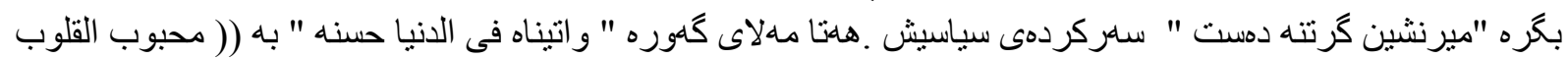

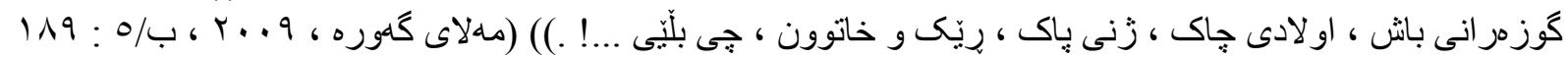

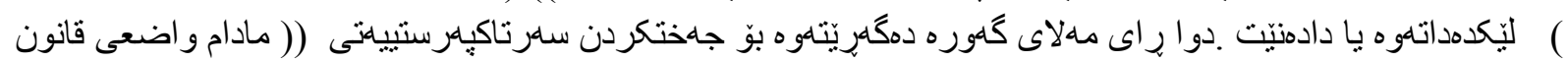




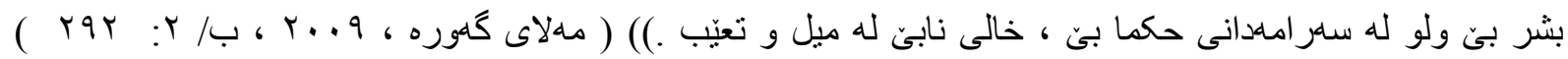

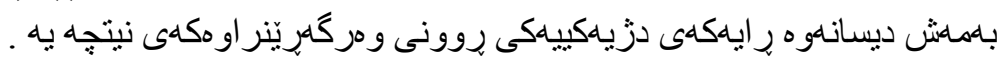

\section{ئنانجام}

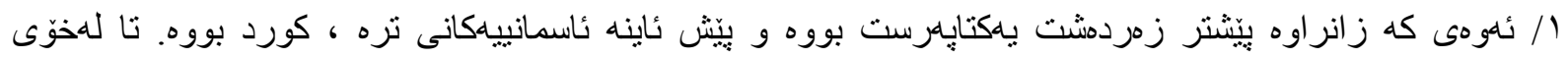

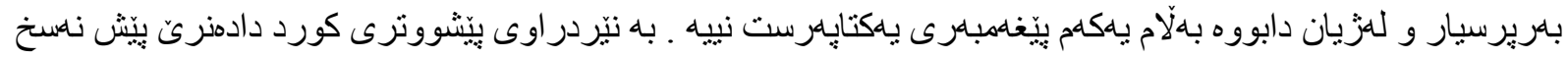

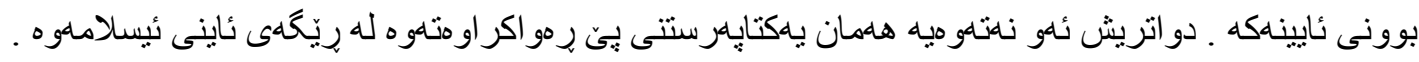

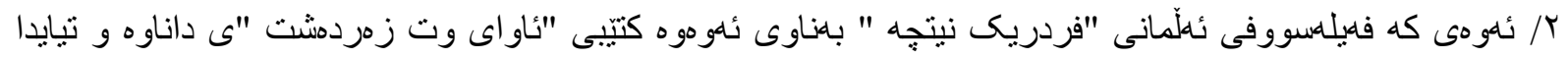

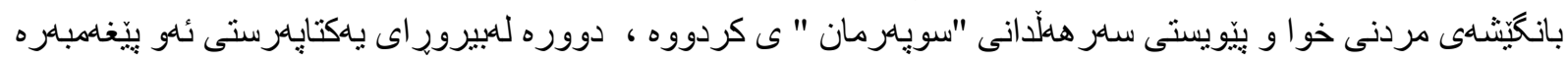

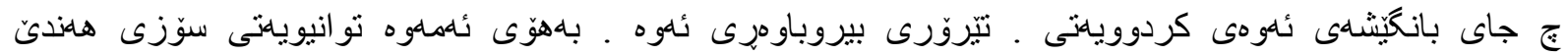

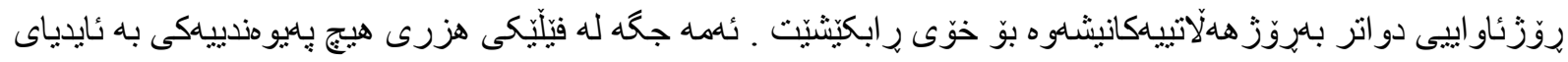

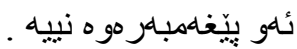

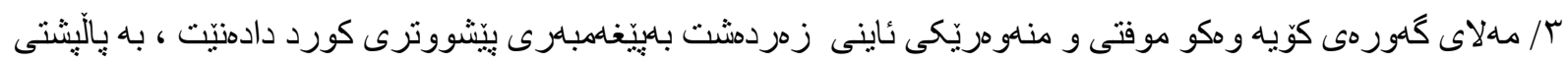

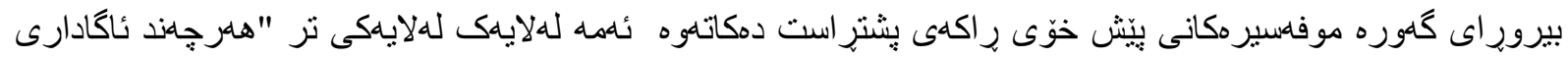

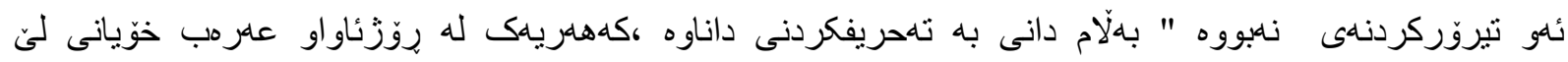

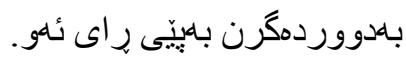

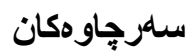

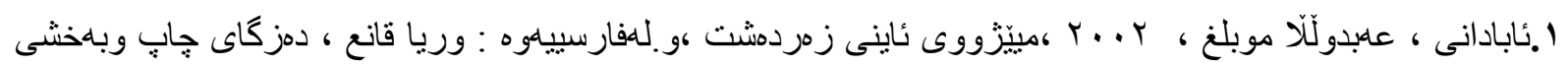

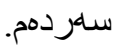

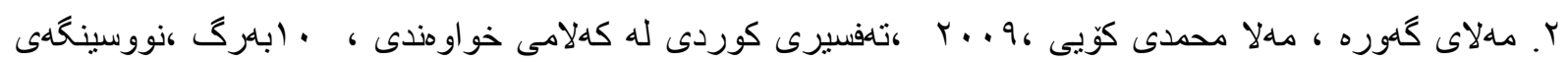

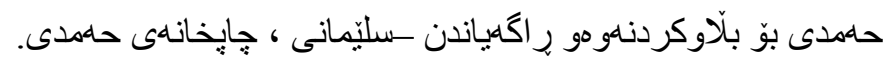

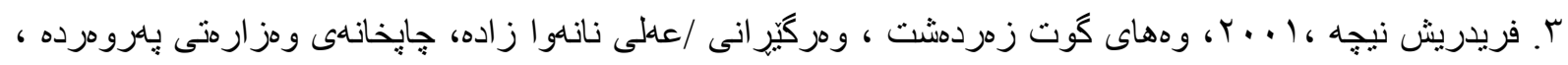

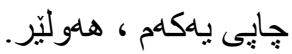

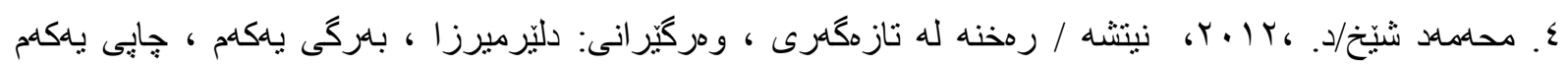

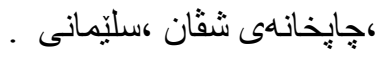

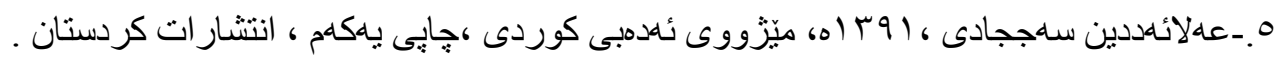

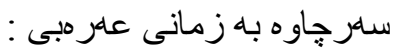
1. ايريش فروم ، 1 1 ـ r،جوهر الانسان ، ترجمه سلام خيرى بك ، الطبعه الاولى ، دار الحوار للنشر و التوزيع ، سوريه.

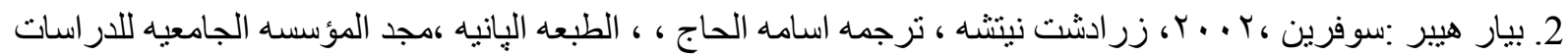

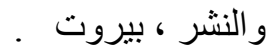

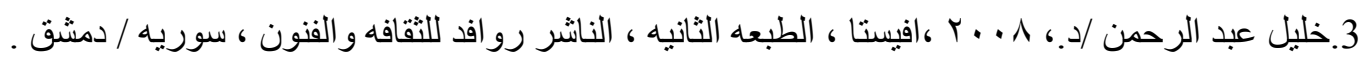


4. حسن نعمه ، ـ 99 (،موسو عه الاديان السماويه و الارضيه ، ميثولوجيا واساطير الثعوب القديمه و معجم المعبودات

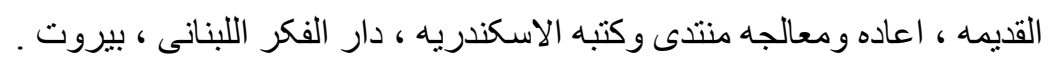
5. ستيفان اودويف ، 1919 ، على دروب زر ادشت ، ترجمه د. فؤاد ايوب ، دار دمشق ، الطبعه الاولى ، دمشق.

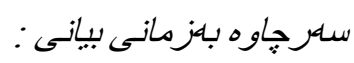

(Fridrich Nietzsche, 1999 , Thus Spake ZaradJustra, Copy right (C) The Pnnsylvania state University.)

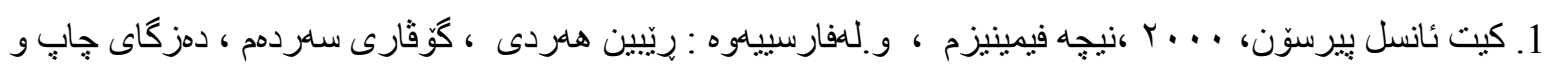

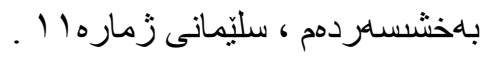

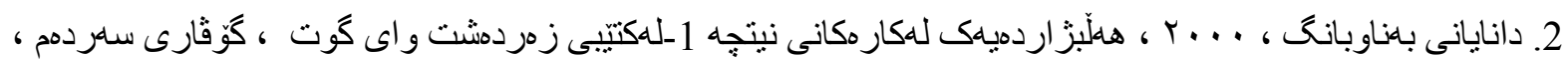

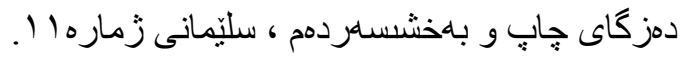

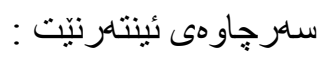

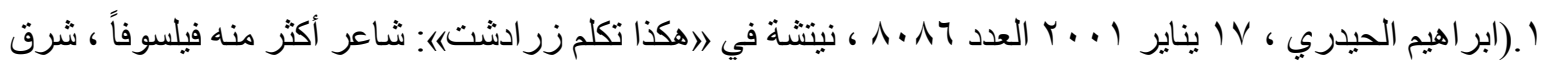

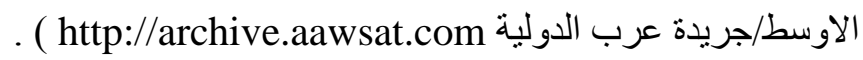

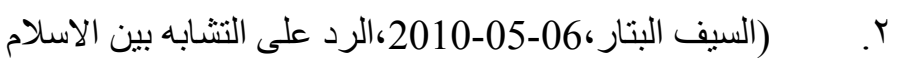

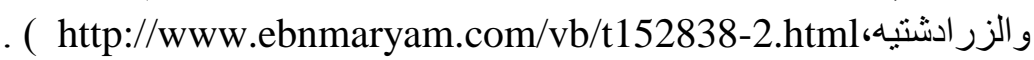
r. (جمال جويرب المهيرى ، المر اه فخ نصبته الطبيعه، www.albayan .ae 2012 ).

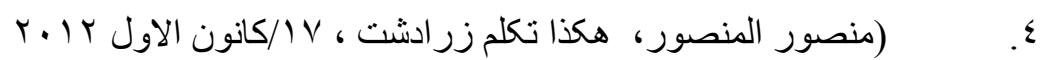
( /HTTP://WWW.KITABAT.COM •. 2012/2/28 . ((/HTTP://WWW.BAHZANI.NET 7. ( مدونه بروميثيوس ، فلسفه: السوبرمان هو الاّنسان الذى يتجاوز ذاته دائماً ، 2011 2015/HTTP:/SHADOWOFPROMETHEUS.BLOGSPOT.CO )

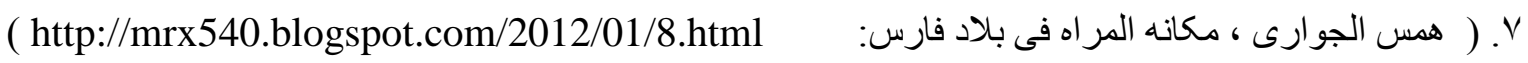
ATTP://WWW.FREE- 2009/12/12 ، مهدى مجيد عبداله، زاردشت الرسول الحقيقى للقوميه الكورديه ) - ( /PENS.ORG

(Franz Cardinal König, Zoroaster-Iranian-prophet, [Online] Available at:. 9 https://www.britannica.com/biography/Zoroaster-Iranian-prophet) 